\title{
International Financial Organizations in the Economic Modernization Processes of Countries
}

\section{SVITLANA SIDENKO ${ }^{1}$, MAKSYM KULBIDA ${ }^{2}$}

\begin{abstract}
The article is devoted to substantiation of theoretical and practical aspects of the functioning of international financial organizations, which play a key role in the system of international economic relations and global governance, at the same time, being an integral part of the world economy. The article analyzes the current trends and patterns of operation of IFO, identifies determinants and social and economic consequences of cooperation with them for countries in different regions of the world. The research uses a systematic approach; the methodological basis of the work includes the provisions of theories and concepts of development of international financial organizations, conceptual approaches to the study of IFO cooperation with countries. The source and statistical basis of the article are fundamental monographic studies and periodical publications of domestic and foreign scientists, materials and analytical reports of the International Monetary Fund, the World Bank and other international organizations, as well as laws and regulations of Ukraine on issues of cooperation with international financial organizations, credit, monetary and exchange rate policy, statistical and analytical data of the National Bank of Ukraine, State Statistics Service of Ukraine, Ministry of Finance of Ukraine, etc. The article examines the objective causes and evolution of IFO and the strengthening of their impact on the world economy; problems of global governance, it was established that in modern international relations it is characterized as a process of joint governance, uniting governments of the world, international nongovernmental organizations and civil society institutions with the aim to achieve common goals. Features and essential characteristics of the place and role of IFO in the global system of governance and impact on social and economic transformations in the world have been considered and it has been found that they are key elements of the institutional framework of the global financial system in globalization, play a key role in regulating international economic relations and promote active participation of countries in international monetary relations, play the role of a crisis manager and are a reliable and stable source of short- and long-term financing of priority development projects. The formation, development and prospects of cooperation of IFO with the countries of the world, in particular the countries of Latin America, Eastern Europe and East Asia have been analyzed. The main social and economic consequences of cooperation and financial assistance of the IMF on the dynamics of macroeconomic and social indicators of the national economy have been identified.
\end{abstract}

KEY WORDS: international financial organizations, International Monetary Fund, global financial architecture, global governance, social and economic development.

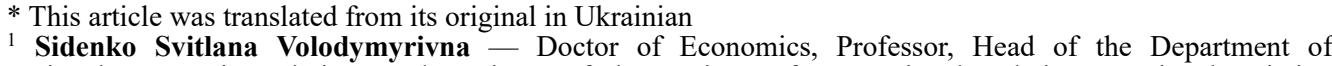
International Economic Relations and Business of the Institute of International Relations, National Aviation University. Author of more than 170 scientific and methodological works, including two monographs and chapters in 20 collective monographs, scientific guides (co-authored) published in Ukraine and abroad. Sphere of scientific interest: problems of globalization of economy, European integration, competitiveness of economy, innovation development, market models, social development. E-mail: sv sidenko@ukr.net

2 Kulbida Maksym Valeriiovych - PhD, intern at the Council of Europe (Strasbourg, France). Sphere of scientific interest: international finance, international financial institutions, world financial architecture. E-mail: kulbidamax@yahoo.com.
}

IEP, No. 32-33 (2020), pp. 99-138

(C) Svitlana Sidenko, Maksym Kulbida, 2020 «All rights reserved»

ISSN 1811-9832/2020/No. 1-2 (32-33) 


\section{Introduction}

In the context of economic globalization, international financial organizations are a key mechanism for regulating the international monetary and financial system, as well as the main source of financial, technical and analytical assistance to countries on the way to the implementation of social and economic transformations. The study of the role of international financial organizations in the development of economic globalization, in particular in the context of the occurrence of crisis phenomena, as well as determination of the main directions for reformation of the mechanisms of cooperation between IFO and countries that are making the transition or introduce the basic principles of a market economy in the field of social and economic development are extremely relevant for Ukraine.

The theoretical foundations of genesis and evolution of IFO, reform of the world financial system, the laws of IFO functioning in the world economy, the forms and levels of IFO interaction with national economies, as well as the formation and modifications of the global financial architecture were the subject of research in the works of foreign scientists, including Boughton $\mathrm{J}^{3}$, Bradlow D. ${ }^{4}$, Williamson $\mathrm{J}^{5}$, McDowell D. ${ }^{6}$, Naciri A. ${ }^{7}$, Ocampo J. ${ }^{8}$, Stiglitz J. ${ }^{9}$, Sinclair J. ${ }^{10}$, Soros G. ${ }^{11}$, Truman E. ${ }^{12}$ and others. For domestic science, the study of IFO development is a little-studied area, although it has important theoretical and practical significance. The issues of IFO cooperation with the countries of the world, in particular with Ukraine, advantages and disadvantages of such cooperation are the subject of research in the works of such domestic scientists as: Bilorus O. ${ }^{13}$, Danylyshyn B. ${ }^{14}$, IMF.

${ }^{3}$ Boughton J. M. (2001) Silent revolution: the International Monetary Fund, 1979-1989. Washington D.C. :

${ }^{4}$ Bradlow D., Hunter D. (2010) International Financial Institutions and International Law. New York : Kluwer Law International.

5 Williamson J. A. (2008) Short History of the Washington Consensus. In: Serra N., Stiglitz J., eds. The Washington Consensus Reconsidered: Towards a New Global Governance. Oxford: Oxford University Press, p. 14-30.

${ }^{6}$ McDowell D. (2017) Brother, Can You Spare a Billion? (The United States, the IMF, and the International Lender of Last Resort). Oxford : Oxford University Press.

${ }^{7}$ Naciri A. (2018) The Governance Structures of the Bretton Woods Financial Institutions. Montreal : Springer.

8 Ocampo J. A. and Titelman D. (2012) Regional Monetary Cooperation in Latin America. ADBI Working Paper 373. Tokyo : ADBI.

${ }_{9}^{9}$ Stiglitz J. (2018) Globalization and Its Discontents Revisited: Anti-Globalization in the Era of Trump. New York : W. W. Norton \& Company.

${ }^{10}$ Sinclair J. T. (2012) Global Governance. Cambridge : Police Press.

11 Soros J. (2018) Open Society. Reforming global capitalism. Translation from English. A. Pitik, E. Hrytsaychuk. Kharkiv: Folio. [In Ukrainian].

${ }^{12}$ Truman E. (2006) Reforming the IMF for the 21st Century. Washington D.C. : Institute of International Economics.

${ }_{13}$ Bilorus O.G., Yefimenko T.I. (2015) Financial globalization and European integration (ukr. Finansova hlobalizatsiia i yevrointehratsiia). Kyiv: AFU. [In Ukrainian]. 
Kolosova V. ${ }^{15}$, Klymenko K. ${ }^{16}$, Liutyi I. ${ }^{17}$, Mozhovyi O. ${ }^{18}$, Rohach O. ${ }^{19}$, Sidenko V. ${ }^{20}$, Filipenko A. ${ }^{21}$ and others.

The purpose of the article is to clarify the advantages and disadvantages of IFO cooperation with countries and proposals for optimization of such cooperation with Ukraine.

\section{IFO in the system of global governance}

Since the end of the last century, world development has been influenced by the influence of globalization processes, which have already been thoroughly studied ${ }^{22}$. The phenomenon of globalization is the formation of a single interconnected world in which the factors of the global order not only strengthen its previously incomplete fragments, but also have a transformative effect on them ${ }^{23}$. Studies of these processes have shown that the current wave of globalization is characterized by large-scale movement between countries of flows of goods and services, capital and people and at the same time global communications and information systems, international economic and financial organizations and corporations form the fabric of the world economy, in which all national economies without exception are intertwined to a greater or lesser extent ${ }^{24}$.

${ }^{14}$ Danylyshyn B.M. (2016) Cooperation with the IMF: problems and prospects (ukr. Spivrobitnytstvo z MVF: problemy $\mathrm{i}$ perspektyvy). URL: https://dt.ua/macrolevel/spivrobitnictvo-z-mvf-problemi-i-perspektivi-_.html. [In Ukrainian].

15 Kolosova V.P. (2016) Finance of international institutions in Ukraine (ukr. Spivrobitnytstvo z MVF: problemy i perspektyvy). Kyiv: KNTEU. [In Ukrainian].

${ }^{16}$ Klymenko K.V. (2017) Foreign experience of cooperation with the International Bank for Reconstruction and Development and the International Development Association (ukr. Zarubizhnyi dosvid spivrobitnytstva $\mathrm{z}$ Mizhnarodnykh bankom rekonstruktsii ta rozvytku i Mizhnarodnoiu asotsiatsiieiu rozvytku). Scientific works of NDFI (ukr. Naukovi roboty NDFI), No. 1, p. 16-40. [In Ukrainian].

17 Liutyi I.O. (2008) State credit and debt policy of Ukraine (ukr. Derzhavnyi kredyt ta borhova polityka Ukrainy). Kyiv: Center for Educational Literature (ukr. Tsentr uchbovoi literatury), p. 139-238. [In Ukrainian].

18 International Finance (2016) /ed. by O.M. Mozgivyi et al.. Kyiv: KNEU. [In Ukrainian].

${ }^{19}$ World finances: modern tendencies and prospects of development: monograph (ukr. Svitovi finansy: suchasni tendentsii ta perspektyvy rozvytku ) (2013) / O.I. Rohach et al. Kyiv: KNU. [In Ukrainian].

${ }^{20}$ Sidenko V.R. (2017) Difficult dilemmas of renewing the global institutional architectonics (ukr. Trudnyie dilemmyi obnovleniya globalnoy institutsionalnoy arhitektoniki). Economy of Ukraine (ukr. Ekonomika Ukrainyi), No. 4 (657).- p. 3-21. [In Russian].

21 Filipenko A.S. (2010) Economic globalization: origins and results (rus. Ekonomicheskaya globalizatsiya: istoki i rezultatyi). Moscow: Economics (rus. Ekonomika). [In Russian].

22 Brzezinski Z. Out of Control: Global Turmoil on the Eve of the 21 st Century. N.Y., Maxwell Macmillan Int. 1993; Huntington S. The Clash of Civilizations //Foreign Affairs. 1993. No. 72; The Clash of Civilizations and the Remaking of World Order. N. Y., Simon \& Schuster, 1996; Santoro C. Progetto di ricarsa multi funzionale 1994 1995 // I nuovi poli geopolitici. Milano, 1994; Wallerstein I. After Liberalism. N.Y., New Press, 1995 Soros G. The Crisis of Global Capitalism: Open Society Endangered. N. Y., Public Affairs, 1998; Vellinga M. The Dialectics of Globalization.Boulder, Col. (USA), Oxford (UK); Westview Press, 2000.

${ }^{23}$ Ilyin M.V., Inozemtsev V.L. Megatrends of world development (rus. Megatrendyi mirovogo razvitiya). [In Russian].

${ }^{24}$ Bogomolov O.T., Nekipelov A.N. Economic globalization and the crisis of the world economic order (rus. Ekonomicheskaya globalizatsiya i krizis mirovogo hozyaytvennogo poryadka). — Facets of Globalization (rus. Grani globalizatsii). — p.105. [In Russian]. 
A number of qualitative and quantitative changes taking place in the world economy in the context of globalization, allow us to identify its main elements and features. As noted by Soros G., "a notable feature of the global capitalist system is the mobility of capital, information and entrepreneurship" 25 . First of all, globalization is accompanied by the rapid development of trade and economic relations - the growth rate of world trade is outpacing the growth of world gross domestic product, while the share of GDP exports to the world is growing significantly. Thus, in 2018, world exports amounted to USD 19453 billion and had increased by $9.4 \%$ compared to 2011, and world imports amounted to USD 19774 billion and had increased by $9.3 \%$ compared to $2011^{26}$. The organizational structure of many sectors of the world economy has been based on global value chains, which function as multinational network structures that assign to each nation only a part of the value creation process. The fragmentation of international production has significantly changed the architecture of the world economy.

Global trends in the internationalization of production and capital, the development of strategic alliances and the liberalization of foreign trade have placed international corporations at the center of the world economic development, which are the "drivers of the world economy", an integral part of the modern system of international economic relations. According to UNCTAD, there are about 82,000 multinational companies and 825,000 foreign affiliates in the world, and their number has increased 12 times over the past 30 years and is growing every year $^{27}$. In a competitive business environment, 500 largest multinational companies sell $95 \%$ of the world's pharmaceutical products, about $80 \%$ of the world's electronics and chemistry, $76 \%$ of the world's engineering products. They control almost half of world industrial production and two-thirds of international trade, as well as $4 / 5$ of patents and licenses for the implementation of new technologies and their incomes from sales often exceed the budgets of even developed countries.

The processes of international migration have developed unprecedentedly. Therefore, according to the UN, the number of international migrants in the world reached 272 million people in 2019, which is 51 million more than in 2010. Migrants now make up 3.5\% of the world's population (for comparison, in 2000 they amounted to $2.8 \%)^{28}$. The most dynamic processes in the context of globalization are

${ }^{25}$ Soros G. The Crisis of Global Capitalism: Open Society Endangered. N. Y., Public Affairs, 1998. [In Ukrainian]

${ }_{26} 2017$ Handbook of Statistics - UNCTAD, https://www.unctad.org/en/PublicationsLibrary/tdstat42_en.pdf; 2019 Handbook of Statistics - UNCTAD, https://unctad.org/en/PublicationsLibrary/tdstat44 en.pdf.).

${ }^{27}$ World Investment Report 2017: Investment and Trade Development. - 2017. URL: http://unctad.org.

${ }^{28}$ The number of migrants in the society exceeded 270 million. URL: https://www.ukrinform.ua/rubricworld/2782330-kilkist-migrantiv-u-sviti-perevisila-270-miljoniv.html. [In Ukrainian]. 
present in the financial sector. Annual currency trading is about 80 times higher than world trade in goods, turnover in the international stock and currency markets is tens or even hundreds of times higher than trade turnover. Exports of capital in the form of direct investment are growing 2-3 times faster than the world trade. As noted by Soros G., the global economy is characterized not only by free trade in goods and services, but even more it is characterized by the free movement of capital; global financial markets have a strong influence on economic conditions. All these changes have a significant impact on the economy, world economy, international relations, mentality and life of millions of people in the world.

The study of the process of globalization allows us to note a number of positive trends in world development, in particular: rapid economic growth in many countries as a result of opening markets for international trade, increase of foreign investment, expansion of new technologies, creation of millions of jobs, deregulation and increase of market flexibility have stimulated economic growth and living standards, significantly expanded the range of available consumer goods, created conditions for the free dissemination of information in previously closed societies. Moreover, the poorest countries, given their lower baseline, have been growing faster.

Assessing the impact of globalization on world development, Nobel Laureate Stiglitz J. noted that the opening of markets for international trade has helped many countries achieve much faster economic growth than they would otherwise have. Export-driven growth has been a central point of industrial policy, enriched Asia and significantly improved the lives of millions. Due to globalization, life expectancy has increased in many nations of the world, their standard of living has also increased $^{29}$.

The spread of transnationalisation processes has had a positive effect in development of countries. In this regard, findings of Toynbee A. J., a British scientist, researcher of civilizations, who noted that the successful expansion of Western civilization beyond its own civilizational boundaries pushed the countries, that are the object of such expansion, to modernization associated with the assimilation of some special elements of Western civilization, are relevant. Modernization and transformation consisted, on the one hand, of the adaptation of forms of mass production to the local civilization specifics and, consequently, in the promotion of Western engineering and

\footnotetext{
${ }^{29}$ Stiglitz D. Globalization: disturbing trends. — transl. from English, M., Mysl, 2003. [In Russian].
} 
technology in new social and cultural regions, and on the other, of the adaptation of the political forms of modern democracy ${ }^{30}$.

In general, global markets, global technologies, global ideas and global solidarity can enrich people's lives in all countries and greatly expand choice opportunities. The growth of interdependence between people stimulates the formation of common values and promotes human development on a global scale. It can be said that we are seeing the creation of a global community, which is called a mega-society, within which there is a single interdependent, interconnected and interpenetrating world. Large and small human communities are increasingly influencing each other, the fates of the inhabitants of the planet are becoming more and more close and inseparable.

At the same time, the study of the modern process of globalization shows that the global economy is not an economy on a planetary scale, i.e. it does not cover all economic processes, territories and people, although it has an impact on all mankind. The segmental nature of the global economy has been pointed out by many foreign researchers. In particular Castells M., a specialist in the field of information society, notes that "despite the planetary effect of the global economy, its existence and forms affect only certain segments and economic structures, countries and regions in proportion to the specific position of the country or region in the international division of labor" ${ }^{1}$. It is already clear that the global economy is characterized by a fundamental asymmetry between countries in terms of their level of integration, competitiveness and the share of benefits from economic growth. At the same time, one of the positive consequences of globalization is the growth of the possibility of multi-variety in the realization of the national interests of the world community member states.

While noting the positive aspects of the spread of globalization, it is necessary to take into account the new problems and contradictions created by this process, which are an objective factor and a source of continuous development of the world economic system. These contradictions in the modern scientific literature are seen as global challenges, which should be understood as global problems, which are the result of new transformational trends in the world economy, disrupting the overall dynamics of sustainable reproduction of social and political, social and economic and legal intercivilizational relations within the new world order. The concept of "global challenges" was

${ }^{30}$ Toynbee A. J. Civilization before the Court of History: A Collection. — transl. from English. — 2nd ed. M.: Iris-press. 2003. [In Russian]. Russian].

Castells M. Information Age: Economics, Society and Culture .: transl. from Eng. — M .: GU HSE, 2000. [In 
introduced in the works of Toynbee A. in the middle of the twentieth century, but it became extremely relevant at the turn of the XX and XXI centuries.

According to the definition of the German sociologist Beck U, global problems are the result of nonlinear processes of world development and are characterized by dynamism, complexity, interdependence, great severity, historical hierarchy, etc. ${ }^{32}$. Therefore, the study of current trends and transformations of the world economy is an urgent theoretical and applied problem.

According to the winners of the 2019 Nobel Prize in Economics, Banerjee A. V. and Duflo E., distrust to governments, social stratification, political upheaval were added to the global problems of migration, economic inequality and the environment.

Differences between people and political parties are becoming more acute, one party does not hear the other ${ }^{33}$. Along with the growing interdependence of the world, the mutual vulnerability of different countries is growing, which exacerbates the problems of national economic, social, informational and military security. The spread of crisis phenomena is becoming faster and larger in the world economy, which was clearly demonstrated by regional crises in the second half of the 1990s, the global financial crisis of 2008, and the crisis caused by the COVID-19 pandemic. Accelerating the development of information technology requires increasing protection of personal data. The emergence of increasingly sophisticated viruses threatens to disrupt global computer systems. Differences in religious and cultural identification are a source of tension among countries and peoples. The rivalry of nationalist aspirations poses a threat to collective security. Moreover, this list of new global threats can be extended. Harari Y. notes that the world is becoming more global, and its impact on individuals and society as a whole, on our behavior and morals is growing. Against the background of the revolution in information technology and artificial intelligence, issues of further confidence in liberalism, the free market and human rights are deadlocked ${ }^{34}$.

At present, none of the countries is ready to take responsibility for providing the social benefits necessary for the efficient function and sustainability of the world economy, as well as effective control over international institutions, which maintain the openness of the trading

\footnotetext{
${ }^{32}$ Beck U. What is globalization / U. Beck. - M .: Progress-Tradition, 2001. - 304 p. [In Russian].

${ }^{33}$ Banerjee A. V., Duflo E. (2019) Good Economics for Hard Times New York : Public Affairs.

${ }^{34}$ Harari Y. N. (2018) 21 Lessons for the 21st Century. London: Vintage.
} 
system, maintain the stability of the monetary system and ensure the proper function of global financial markets ${ }^{35}$.

In such circumstances, the coordination and determination of directions of development at the international level requires the adoption of joint informed decisions and national interests are more and more often crossing national borders. Emergence of new markets (foreign exchange and capital, combined at the global level), new tools (Internet, information networks), new organizations (WTO, multinational corporations), international production networks, new rules (multilateral agreements on trade, services, intellectual property, which limit the prerogatives of national policy and have a binding force for national governments), international migration and global risks necessitate the formation of global institutions. The extremely high level of economic interdependence around the world reinforces the need to establish a system of global governance. The implementation of mechanisms and principles of global governance takes into account the peculiarities of the modern stage of globalization, which meet the Sustainable Development Goals for 2016-2030 (The 2030 Agenda for Sustainable Development), which were approved by the UN General Assembly.

The search for global governance institutions has been underway for a long time and there are different opinions about the options and capabilities of its functioning. Back in the early 30's of the last century Wells G. put forward the idea of creation of a World Federal State with broad powers. During the formation of the UNO Einstein A. and Toynbee A. J. put forward the idea of creation of a World Coalition Government, in this regard. Some researchers note the possibility and necessity of creation of a single world legal framework and world bodies of economic and political governance. In the 70's and 80's of the last century it was predicted formation of the world government in the future as a possible mechanism of global governance. At the same time, some theorists, by moving the concepts of public administration at the national level to the global level, are trying to present leading international organizations as a prototype of the future of global government and the most effective tool capable of ensuring the management of the world community and the world economy. However, real processes of global development prove that, at present, these ideas are utopian.

\footnotetext{
${ }^{35}$ Reznikova N.V., Ivashchenko O.A. (2017). Problems of reinstitutionalization of the world economy in the conditions of independence: new challenges to global regulation (ukr. Problemy reinstytutsionalizatsii svitovoi ekonomiky v umovakh neozalezhnosti: novi vyklyky hlobalnomu rehuliuvanniu). Economics (ukr. Ekonomichna nauka), No. 10, p. 5-6. [In Ukrainian].
} 
Since the process of modern globalization has been developing for not a very long time, it has not yet become institutionally designed and regulated, since the relevant structures and mechanisms of governance have not been created. On this occasion, Stiglitz J. notes that "we do not have a world government responsible for the peoples of all countries, to control the process of globalization in ways comparable to the way in which national governments directed the processes of nation formation. Instead, we have a system that can be called global governance without a global government, the one in which a bunch of institutions: the World Bank, the IMF, the WTO and a bunch of players: the ministries of finance, domestic and foreign trade, closely linked to financial and commercial interests, together dominate the stage, but at the same time a huge majority, to whom their decisions apply to, remains almost voiceless ${ }^{36}$.

Under these conditions, a need for the development of international organizations of different orientation arose to effectively regulate relations among countries. The concept of global governance is relatively new in international relations and is characterized as a process of joint governance, unifying governments of countries, international non-governmental organizations and institutions of civil society for achievement of common goals ${ }^{37}$. Barnett M. N. and Finnemore M., in their research "Rules for the World"38 and "Politics, Power and Pathologies of International Organizations"39 consider international organizations as institutions that have some autonomy from their founders and who create their own regulatory rules that directly affect their activities.

P. Keohane notes that the establishment and strengthening of international institutions is the key to effective cooperation among the countries, as they operate on the basis of certain rules, obligations and membership, requiring each party to strictly comply with them with the aim to jointly seek to solve their own problems ${ }^{40}$. In today's environment, some global governance institutions and global problems are already being solved at the level of the United Nations, the International Labour Organization, the World Bank, the International

\footnotetext{
${ }^{36}$ Stiglitz D. Globalization: disturbing trends. — transl. from English, M., Mysl, 2003. [In Russian]. - p. 41.

${ }^{37}$ Kulbida M. (2019) International financial organizations in the system of global governance (ukr. Mizhnarodni finansovi orhanizatsii u systemi hlobalnoho upravlinnia). Current issues of international relations (ukr. Aktualni problemy mizhnarodnykh vidnosyn): materials of the International. scientific-practical conf., October 24, 2019, Kyiv: IIU KNU, p. 138-141. [In Ukrainian].

${ }^{38}$ Barnett M. N., Finnemore M. (2004) Rules for the World: International Organizations in the Global Politics. Ithaca : Cornell University Press.

${ }^{39}$ Barnett M. N., Finnemore M. (1999) The Politics, Power, and Pathologies of International Organization. International Organization, 53(4), p. 699-732.

${ }^{40}$ Keohane R. (2005) After Hegemony: Cooperation and Discord in the World Political Economy. Princeton : Princeton University Press.
} 
Monetary Fund, the World Trade Organization, the mechanisms of agreed actions already exist at the level of Group of 20 and Group of 7, as well as numerous non-governmental organizations. USA, common foreign policy of integration groups, in particular, of the European Union and others have some influence on global problems ${ }^{41}$.

According to the Ukrainian scientist Sidenko V.R., a tangible structural transformation in the world economy requires systemic changes in global governance. Since the beginning of the twentieth century, a new vision of the effectiveness criteria for such governance has gradually formed, these criteria are focused on: promotion of global partnership on the basis of strengthening multilateral approaches to problem solving; ensuring social and economic growth, sustainable and equal access in the interests of all parties (especially the most vulnerable ones); the support for developing countries and countries with forming markets; ensuring global food and energy security, etc ${ }^{42}$.

According to experts, globalization, that is, the removal of the barriers to free trade and closer integration of national economies, has great potential for the development, but to implement this task it is necessary to radically reconsider the mechanism of globalization management both in the field of international agreements and in the field of international politics.

\section{Economic globalization and IFOs}

One of the main issues of global governance is financial and economic regulation. International financial organizations are the main regulators of the international monetary and financial system, as well as a significant source of financial, technical and analytical assistance to countries that face short-term problems of the balance of payments or carry out social and economic transformations. Exacerbation of the crisis in the world economy actualizes the activities of IFO, in particular in the prediction, prevention and overcoming of their consequences.

The International Monetary Fund and the World Bank are the result of the 1944 Bretton Wood Conference, which aimed to create a foundation for economic cooperation and development aimed at strengthening and growing of the global economy. This goal continues to be the main one for both organizations, but their activities are constantly adapting to changes in economic development and the

41 Lukyanenko D.H., Kalchenko T.V. (2008). Strategies of global governance. International Economic Policy, No. $1-2$, p. $5-43$.

42 Sidenko V.R. (2018). Global structural transformations and trends of the Ukrainian economy (ukr. Hlobalni strukturni transformatsii ta trendy ekonomiky Ukrainy). Economics and Forecasting (ukr. Ekonomika $\mathrm{i}$ prohnozuvannia), 2, p. 7-28. [In Ukrainian]. 
emergence of new global challenges. The IMF activities focus on macroeconomic and financial stability issues, while the World Bank's activities focus on long-term economic growth and poverty eradication.

The formation of a modern IFO system was preceded by several stages. The impetus for the formation of IFO was the industrial revolution that took place in Western Europe, USA and Japan in the second half of the XIX century. The intensification of financial relations between two countries has made it necessary to combine their efforts. A qualitatively new stage in the development of International Monetary relations was the "classic gold standard", which was revolutionary at that time ${ }^{43}$. The Paris conference, held in 1867, recognized gold as the main unit of international settlement and for the first time outlined the direction of unification of various monetary systems, and the "gold standard" became the first international monetary system ${ }^{44}$.

After the first World War, countries began to rebuild their economies and convened the Genoa Economic and Financial Conference, held in 1922 , to return to the pre-war economic regime, but speculative and unsuccessful policies led to a deterioration in the financial situation, which led to the first world financial crisis, known as the Great Depression of 1929-1933. Nevertheless, the decisions of the conference represent a significant step towards creation of the foundations for multilateral international legal regulation of economic relations among countries $^{45}$.

One of the consequences of the first global economic crisis was the creation in 1930 of the first IFO - the Bank for International Settlements (BIS), which was supposed to coordinate the policies of central banks and financial institutions of various countries, in particular, Belgium, Great Britain, Germany, Italy, France, and Japan. The main task of the BIS was to promote cooperation between the central banks of the countries, facilitate the conditions of international financial transactions and international regulation of monetary, credit, and financial relations. Although the activities of this financial institution did not lead to tangible and effective results until the end of World War II, it marked the beginning of the formation of the IFO system.

Moreover, the causes of the appearance of IFO were the need to create a new international monetary system that would establish economic order after the financial chaos between the two World Wars:

\footnotetext{
43 Filipenko A.S. (2010) Economic globalization: origins and results (rus. Ekonomicheskaya globalizatsiya: istoki i rezultatyi). Moscow: Economics (rus. Ekonomika). [In Russian].

${ }_{44}^{4}$ Ricards J. (2015) Currency Wars. Moscow: Eskmo, p. 72.

45 Moiseev A.A. (2007). International financial organizations (legal aspects of activity). 2nd ed. Moscow: OMEGA, p. 10. [In Russian].
} 
hyperinflation in some countries, painful deflationary processes in others during the 1920s, the collapse of the gold standard, and the Great Depression.

The end of World War II was marked by the creation of the most important international organization of our time - the UNO, whose activities mainly concern security and peace issues. In addition, important organizations have been established to manage the world economy, including the International Monetary Fund and the International Bank for Reconstruction and Development, which are the result of the 1944 Bretton Woods Conference (officially known as the United Nations Monetary and Financial Conference). The main focus of this conference was on the concepts of Harry White (representative of the US Treasury Department) and John Keynes (representative of the UK Treasury Department). The core of the New Order, called the Bretton Woods System, was the configuration of fixed but corrective exchange rates of various currencies against the US dollar, the value of which was fixed in gold.

The Bretton Woods Conference actually addressed the future structure and principles of global governance. If the plan of Keynes J. provided for global governance based on data from organizations that are purely technical in nature, have a minimum of powers, and are actually apolitical, leaving the key political role in international regulation to states, then the plan of White $H$. provided for a qualitatively different approach, namely - he laid the foundations of the global governance based on international financial organizations the IMF and the World Bank - as actors in world politics, having their own political subjectivity, internal norms, goals, tasks and methods of achieving them.

In the 1950s and 1960s, as a result of decolonization processes in the world, in particular in Africa, a large number of newly independent states appeared, which joined in cooperation with the IMF and the World Bank. These countries had significant problems on the path of social and economic transformation and had extremely poorly developed infrastructure. Gaining independence enabled these countries to count on support in development of their economic potential and expertise in public policy. During the development of the economies of these countries, the approach of IFO that aided governments to solve problems of overcoming debt and poverty also changed. In addition, this period was marked by the creation of regional organizations in different parts of the world, such as: Inter-American Development Bank, African Development Bank, Asian Development Bank.

In the 1970s, the International Monetary System again underwent drastic changes: demonetization of gold (loss of the monetary function 
of gold) and the final transition to the use of the world's leading currencies in international settlements, as well as the creation, under the auspices of the IMF, of a new form of international reserve asset Special Drawing Rights (SDR), which is an international reserve currency issued and distributed among the fund's member countries. It is used for non-cash international payments, purchasing foreign currency, and issuing loans. This idea most of all met the needs of internationalization of World Economic Relations, which developed from the end of the twentieth century into the globalization of the world economy.

The growing role of IFO in the context of economic globalization is due to the following factors:

- increased internationalization of economic life and rapid development of multinational corporations and multinational banks, whose activities have gone beyond the borders of national economies;

- deepening the processes of globalization in the economic and financial spheres;

- expansion of inter-state forms of regulation of monetary, credit and financial relations as a component of regulation of international economic relations;

- need to create organizational bases for an inter-state mechanism for jointly solving monetary and financial problems of global economic development due to the increasing instability of the International Monetary System and financial markets ${ }^{46}$.

Thanks to the intensification of globalization and interdependence between developed and developing countries, the goals and functions of IFO have become more visible. In addition, intangible assistance, especially to developing countries and the poorest countries began to play one of the main functions of their activities (Table 1).

It is the appearance of new centers of power and the rapid social and economic development of developing countries along with traditional centers of power is changing the world's architecture towards a multipolar world. The global financial crisis of 2008 finally confirmed the inefficiency of the global financial architecture and global governance and consolidated the G-20 leading position in the global economy.

However, IFO remain an important component of the modern global financial architecture. As noted above, the creation of these organizations dates back to the postwar period, and their function and development are both an important prerequisite and an element of the mechanism of deepening world economic relations. The process of development of international monetary relations has historically and

${ }^{46}$ International Finance / O.I. Rohach et al. Kyiv: Lybid, 2003, p. 541. [In Ukrainian]. 
objectively been characterized by the creation of an extensive institutional structure, which includes universal (global) and regional (multilateral) financial organizations, as well as other monetary and financial institutions.

Table 1

OBJECTIVES AND FUNCTIONS OF IFO ${ }^{47}$

\begin{tabular}{|l|l|}
\hline \multicolumn{1}{|c|}{ Objectives } & \multicolumn{1}{|c|}{ Functions } \\
\hline $\begin{array}{l}\text { stabilization and development of the } \\
\text { international monetary and financial system }\end{array}$ & $\begin{array}{l}\text { act as a regulator of the world economy and } \\
\text { international monetary and financial relations }\end{array}$ \\
\hline $\begin{array}{l}\text { inter-state currency, credit and financial } \\
\text { regulation }\end{array}$ & supervise the international monetary system \\
\hline $\begin{array}{l}\text { development and coordination of strategy and } \\
\text { tactics of development of the international } \\
\text { currency system }\end{array}$ & $\begin{array}{l}\text { stimulate macroeconomic stability and } \\
\text { structural adjustment of the real sector of the } \\
\text { economy }\end{array}$ \\
\hline $\begin{array}{l}\text { accumulation of financial resources and their } \\
\text { use to ensure stability of the national, } \\
\text { regional and world economic development }\end{array}$ & $\begin{array}{l}\text { provide technical assistance and advice to } \\
\text { member-states, as well as share experiences } \\
\text { with the countries undertaking social and } \\
\text { economic transformations }\end{array}$ \\
\hline $\begin{array}{l}\text { collection and analysis of information, as well } \\
\text { as research on international financial relations }\end{array}$ & $\begin{array}{l}\text { monitor the state of the economies of the } \\
\text { member-states and the implementation of their } \\
\text { commitments to IFO }\end{array}$ \\
\hline
\end{tabular}

The main types of IFO are universal (mega-regulators of the financial system), which coordinate monetary relations within the world economy and make a significant contribution to the globalization of financial relations and regional development banks, which finance projects related to economic reform of countries or groups of countries within individual regions. In addition, there are a number of other multilateral development banks, including the Islamic Development Bank, the International Fund for Agricultural Development, the European Investment Bank and the newly created the Asian Infrastructure Investment Bank, each with a relatively limited membership.

The central organization in the world economy and the international monetary system in terms of the scope and universality of membership is the IMF. Appearing after World War II to monitor the international monetary system, the IMF began to play an important, if not a major, role in the global financial architecture. At the same time, it began to play an important role in implementation of the decisions of the world's leading countries - the G-7, as a key link in the implementation of the

\footnotetext{
${ }^{47}$ Developed by the authors based on: Patyka N.I. (2012). International monetary relations. Kyiv: Znannya. [In Ukrainian].
} 
world economic regulation system, the international coordination and the coordination of macroeconomic policies of member-states.

Today, the IMF is the most influential organization that regulates structural parameters of the world economy in general and macroeconomic policy of each member-state, in order to achieve stability in the world economy. Under the new conditions, the IMF developed new instruments, but private sector capital flows moved more freely, and integrated global economy had vulnerability factors and as the result, in the 1980s, a series of large-scale debt crises could be seen. Risks and negative features of globalization began to appear, which caused protests among the population. According to Kolosova V. P., the recent reform of the IMF provides a chance to improve its efficiency, given the positive role it played during the recent global financial crisis, despite the shortcomings of its mandate implementation, in particular in preventing and responding to crises in member-states ${ }^{48}$.

The main mission of the IMF is to ensure the stability of the international monetary system. To fulfill its mandate, the Fund carries out three main areas of activity.

1. Supervises the international monetary system in accordance with Article IV of the Statute of the Annual Economic Policy Assessment and monitors the economic and financial policies of 189 member-states. As part of this process, which takes place both globally and in individual countries, IMF identifies possible risks to the stability of the international monetary system and provides recommendations on the need to adjust global macroeconomic policies. Based on the analysis of tax, monetary and exchange rate policies and the state of balance of payments of countries, recommendations are developed for the development and adjustment of economic, financial and monetary policies of the countries.

2. It provides loans to member countries that have actual or potential balance of payments problems. Financing is carried out within various credit mechanisms, each of which provides for the implementation of a number of conditions and measures by the borrowing country, depending on the social and economic development of the country. The following IMF lending mechanisms can be identified:

- Historically, the core part of the IMF general assistance is provided through the Stand-by Arrangement (SBA), which is designed to help settle short-term balance of payments problems; the program usually lasts 12-24 months;

${ }^{48}$ Kolosova V.P. (2013). Cooperation of Ukraine with international institutions and sectoral budget support (ukr. Spivrobitnytstvo Ukrainy z mizhnarodnymy ustanovamy ta sektoralna biudzhetna pidtrymka). Kyiv: AFU, p. 40. [In Ukrainian]. 
- Flexible Credit Line (FCL) is designed for countries with high and stable economic performance, prudent financial policies and successful experience of the implemented policy, the validity of the FCL varies within 1-2 years;

- Preventive and Liquidity Line (PLL) is designed for countries with stable economic performance due to economic policies and successful implementation of such policies. The duration of PLL varies from 6 months to 2 years;

- Extended Fund Facility (EFF) is designed to help countries settle medium- and long-term balance of payments problems that require fundamental economic reforms. The use of such a mechanism has increased significantly since the 2008 global financial crisis. This mechanism provides for lending for 3-4 years in order to overcome balance of payments difficulties caused by macroeconomic problems in the field of production, trade, pricing;

- Rapid Financing Instrument (RFI) provides rapid financial assistance with a minimum number of conditions for all developing countries without exception and in urgent need of a balance of payments settlement ${ }^{49}$.

As it can be seen from the Figure 1, the use of the IMF credit mechanisms is most in demand during crises, and the most popular were and remain traditional credit mechanisms - SBA and EFF. The number of approved programs is about two main periods: 1995-2004 (crisis period in different regions of the world, in particular in the 90s of the twentieth century) and a new stage of intensification of lending after the global financial crisis of 2008, which led to a revision of both nonconcessional credit mechanisms, and the creation of new credit mechanisms for low-income countries - concessional lending.

The global financial crisis has highlighted the need to revise credit mechanisms not only for developing countries but also for the least developed countries, taking into account the changing economic conditions in these countries and their greater vulnerability to financial crises. In particular, the Fund has revised its lending instruments to better respond to the needs of these countries with short-term balance of payments difficulties, as well as in emergencies.

In 2015, the IMF support for the poorest countries was increased by expanding their access to concessional resources. The fund has implemented a strategy to support soft loans of about USD 2 billion per year for the long term, which is partly funded by contributions related to the distribution of profits from the sale of gold.

\footnotetext{
49 Kulbida M.V. (2018). IMF lending to developing countries (ukr. Kredytuvannia MVF krain, shcho rozvyvaiutsia). Intelligence of the XXI century (ukr. Intelekt KhKhI stolittia), 4, p. 15. [In Ukrainian].
} 


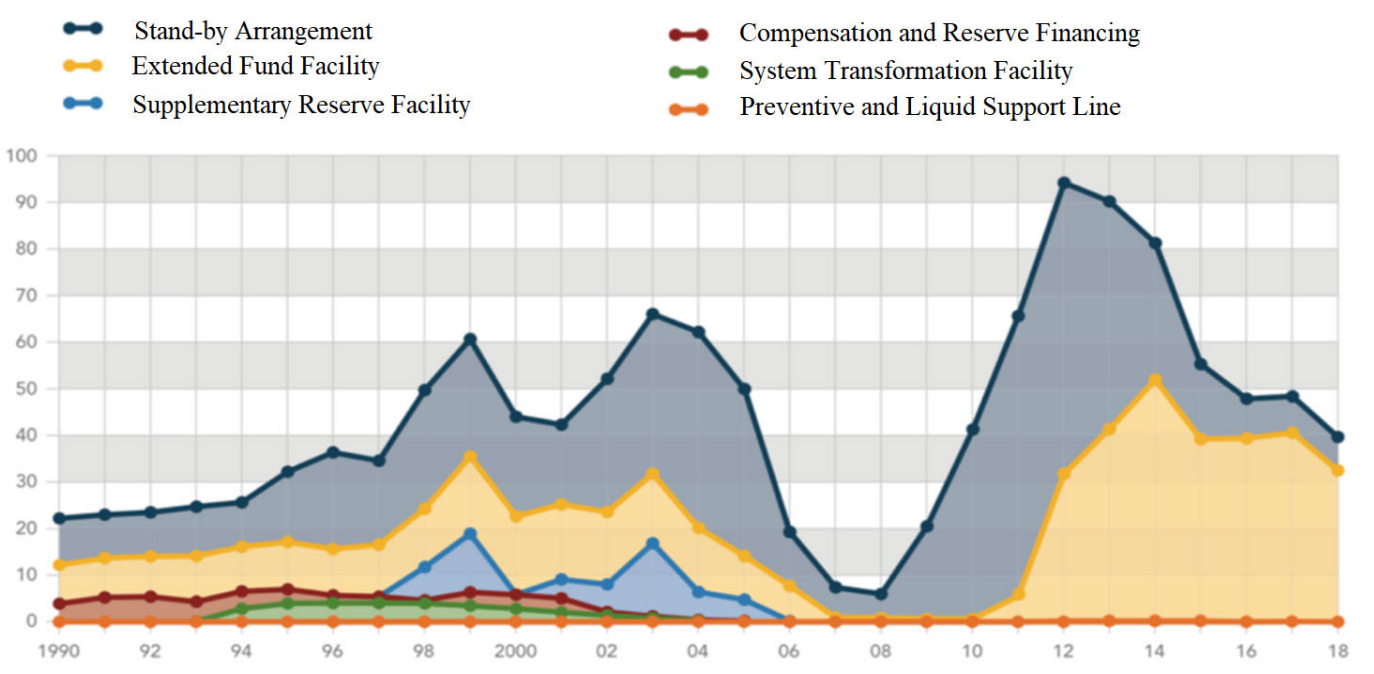

Fig. 1. Dynamics of the IMF lending to member-states, 1990-2018

Currently, the poorest countries can benefit from the following concessional lending mechanisms within the IMF:

- Extended Credit Facility (ECF) is the Fund's main tool for provision of medium-term support to the poorest countries, which have long-standing difficulties with balance of payments deficits. Financing under this Facility is carried out at a zero interest rate, with a grace period of 5 and a half years and a full maturity of 10 years;

- Standby Credit Facility (SCF) is used to provide financial support to the poorest countries that have short-term balance of payments difficulties. This credit mechanism can be used in many cases, including as a precautionary measure, and financing under this mechanism is provided at a zero interest rate, with a grace period of 4 years and a full maturity of 8 years;

- Rapid Credit Facility (RCF) provides rapid financial assistance with a minimum number of requirements for the world's poorest countries who need to maintain their balance of payments immediately. This mechanism allows the IMF to respond in a timely and prompt manner to various unexpected challenges in such countries, and financing under such a mechanism is provided at a zero interest rate, with a grace period of 5 years and a full maturity of 10 years $^{51}$.

\footnotetext{
${ }_{51}^{50}$ Developed by the authors on the basis of IMF data.

51 Kulbida M.V. (2018). IMF lending to developing countries (ukr. Kredytuvannia MVF krain, shcho rozvyvaiutsia). Intelligence of the XXI century (ukr. Intelekt XXI stolittia), No. 4, p. 16. [In Ukrainian].
} 
3. Works with member governments by provision of technical assistance in their monetary and currency, budgetary, fiscal and banking policies, compiling statistics, developing financial and economic legislation, and training for the implementation of the above reforms. Today, technical assistance accounts for more than $20 \%$ of the IMF annual budget. This type of assistance is provided by sending IMF missions to the central banks and finance ministries of member countries. Technical assistance is provided at the request of a memberstate of the Fund.

Finally, it should be emphasized that the IMF is a global center for research and information on international economic and monetary relations, as well as a forum for discussing and finding solutions to various issues. Thousands of reports, articles, studies and notes are published annually within the IMF on various issues of the world economy and economic development and are a source of macroeconomic analysis of various regions and countries, so IMF experts' assessments and research are often the basis of member-states economic policies.

\section{The role of IFO in the processes of social and economic transformations of countries}

At the current stage of development of the world economy, IFO play a key role, as they provide not only financial, technical and analytical assistance to member-states, but also act as regulators of the world economy. Since the 1980s, the world economy has undergone significant transformations due to globalization, the formation of the information society, the development of innovation, radical systemic change, regional and global crises, and technological progress, which significantly affect the development of individual countries and society as a whole. These processes are associated with transnationalisation, innovation, attraction of foreign investment and financial resources of IFO, the use of domestic savings and are based on economic characteristics, mentality, traditions and values of the population, and therefore vary from country to country and have their own specific features.

Issues of social and economic transformations in the countries of the world have been studied by domestic scientists, in particular Varnalii Z. ${ }^{52}$, Halchynskyi A. ${ }^{53}$, Dolishnii M. ${ }^{54}$, Zhalilo Ya. ${ }^{55}$,

\footnotetext{
52 Varnaliy Z.S. (2007). State regional policy of Ukraine: features and strategic priorities (ukr.Derzhavna rehionalna polityka Ukrainy: osoblyvosti ta stratehichni priorytety). Kyiv: NISD. [In Ukrainian].

53 Galchynsky A. (2006) Global transformations: conceptual alternatives: Methodological aspects (ukr. Hlobalni transformatsii: kontseptualni alternatyvy: Metodolohichni aspekty). Kyiv: Lybid. [In Ukrainian]

${ }^{54}$ Dolishniy MI (2006) Regional policy at the turn of the XX-XXI centuries (ukr. Rehionalna polityka na rubezhi 20-21 stolit). Novi priorytety. Kyiv: Nauk. dumka. [In Ukrainian].
} 
Lukinov I. ${ }^{56}$, Lukianenko D. ${ }^{57}$, Sidenko S. ${ }^{58}$, Cukhno A. ${ }^{59}$, Iakovets Yu. ${ }^{60}$ and others. Among foreign scientists, it is necessary to indicate: Baltserovych L. ${ }^{61}$, Kolodko G. ${ }^{62}$, Aslund A. ${ }^{63}$, Friedman T. ${ }^{64}$, Sachs J ${ }^{65}$, Stiglitz J. ${ }^{66}$ and others.

Social and economic systems are continuously undergoing transformations. These changes differ in object (due to cumulative objective processes or conscious reform), in their depth and duration (changes in the quantitative characteristics of certain system parameters within the same quality or transition to other qualitative states), in the coverage of system elements (changes occur in certain parts of the system or at the global level) ${ }^{67}$.

In the general sense, transformation as an economic category is a structural change in the forms and stages of functioning of social systems at different phases of economic cycles. Scientists also note that economic transformation is an organic component of profound fundamental changes in society - in the political, state-administrative structure, as well as in ideology, domestic and foreign policy. This social and economic transformation took place in Eastern and Central Europe, as well as in the Baltic States, South America and Southeast Asia.

Since IFO financial and technical cooperation is a reliable and stable source of both short-term and long-term financing of priority development projects, the countries of the world have attracted credit resources for market reforms under the most favorable conditions for the

55 Zhalilo Ya. A. (2009) Theory and practice of forming an effective economic strategy of the state (ukr. Teoriia ta praktyka formuvannia efektyvnoi ekonomichnoi stratehii derzhavy). Kyiv: NISD. [In Ukrainian].

56 Lukinov II (1997) Economic transformations (at the end of the XXI century) (ukr. Ekonomichni transformatsii (naprykintsi XXI storichchia). Kyiv: IN NASU. [In Ukrainian].

${ }^{57}$ Lukyanenko D.H., Kalchenko T.V. (2008). Strategies of global governance. International Economic Policy, No. 1-2, p. 5-43.

${ }_{58}$ Sidenko S.V. (2011) Non-economic factors of world economic development (ukr. Neekonomichni chynnyky svitovoho ekonomichnoho rozvytku). Kyiv: Aurora-Print. [In Ukrainian].

59 Chukhno A.A. (2003). Post-industrial economy: theory, practice and their significance for Ukraine (ukr. Postindustrialna ekonomika: teoriia, praktyka ta yikh znachennia dlia Ukrainy). Kyiv: Logos. [In Ukrainian].

60 Yakovets Yu. V. (2011). Global economic transformations of the XXI century (rus. Globalnyie ekonomicheskie transformatsii XXI veka). Moscow: Economika. [In Russian].

61 Baltserovich L. (1999) Socialism, capitalism, transformation. Essays at the turn of the century (rus. Sotsializm, kapitalizm, transformatsiya. Ocherki na rubezhe epoh). Moscow: Nauka. [In Russian].

62 Kolodko G.V. (2010) The Great Transformation (rus. Velikaya transformatsiya). Century of Globalization (rus. Vek globalizatsii), No. 2, p. 68-77. [In Russian].

${ }^{63}$ Aslund A. (2013) How capitalism was built : the transformation of Central and Eastern Europe, Russia, the Caucasus, and Central Asia. New York : Cambridge University Press.

${ }^{64}$ Friedman T. (2000) The Lexus and the Olive Tree. New York : Anchor Books.

${ }^{65}$ Sachs J., Tornell A., Velasco A. (1996) The Mexican Peso Crisis: Sudden Death or Death Foretold. Journal of International Economics, No. 3-4, p. 265-283.

${ }^{66}$ Stiglitz J., Serra N. (2008) The Washington Consensus Reconsidered: Towards a New Global Governance. New York : Oxford University Press.

67 Yakovets Yu. V. (2011). Global economic transformations of the XXI century (ukr. Globalnyie ekonomicheskie transformatsii XXI veka). Moscow: Economika. [In Russian]. 
development of strategically important sectors of the economy and infrastructure and to carry out structural reforms, support the state budget and regulate the balance of payments, create the opportunity to access the best international practice, standards and professional expertise of projects.

A leading role in leadership in creation of safe conditions for international economic exchange among countries by building a new international currency system is played by the IMF, which since the 1980s has been actively and systematically dealing with the problems of social consequences of economic restructuring programs, primarily through well-defined measures to reduce short-term adverse effects on income distribution.

It can be argued that during this period the IMF has started to occupy a central place in the world economy, acting not only as the main coordinator of their activities, but also as the main adviser on the development of economies of the world. According to the agreements reached, since then, no organization (including private creditors London and Paris Clubs) has been authorized to provide credit services to any country with a deficit in the balance of payments without the consent of the IMF. According to Bardin A. L., this has become one of the main tools for further political influence of the $\mathrm{IMF}^{68}$.

Let us consider the cooperation of certain regions of the world with the IMF in the context of systemic social and economic transformations. Most Latin American countries joined the IMF and the World Bank at the beginning of their functioning, committing to maintain a fixed but adjusted exchange rate by strengthening a set of control measures, particularly on capital transactions. The analysis of close cooperation between the IMF, the World Bank and the U.S. Treasury Department on economic policy in Latin American countries during the 1980s was based on the principles of the "Washington Consensus", which were summarized by the famous economist Williamson J.:

- reducing the financial deficit to a non-inflationary level;

- redirection of public spending in the field such as education, infrastructure, healthcare, etc.;

- tax reform provides for a broad tax base with moderate marginal tax rates;

- financial liberalization, which includes market-oriented interest rates and should be carried out under prudent supervision and considering domestic economic conditions;

\footnotetext{
${ }^{68}$ Bardin A.L. (2015) The role of international financial institutions in global political governance (Case of the International Monetary Fund and the World Bank) (rus. Rol mezhdunarodnyih finansovyih institutov v globalnom politicheskom upravlenii (na primere Mezhdunarodnogo valyutnogo fonda i Vsemirnogo banka): dis. ... Cand. polit. Sciences: 23.00.04. Moscow: MGIMO, p. 95. [In Russian].
} 
- market exchange rate, which can be competitive at least for trade agreements; that is, in other words, the exchange rate shall be formed by the market;

- trade liberalization (quantitative restrictions shall be lifted and tariff restrictions shall be gradually reduced);

- foreign direct investment shall be encouraged without artificial restrictions, and foreign and domestic companies shall have equal conditions and opportunities;

- privatization of state enterprises;

- deregulation, which aims to simplify restrictions that hinder the emergence of new companies or hinder competition; however, this does not apply to the abolition of restrictions necessary for national security, environmental protection and state price regulation in a non-competitive sector;

- property rights (provision of reliable protection of property rights at the legislative level $)^{69}$.

Thus, the Washington Consensus is a summary of key approaches for the design of effective development strategies associated with the IMF, the World Bank, and the U.S. Treasury Department, and includes three main ideas: market economy, market liberalization and macroeconomic discipline. Cooperation of countries and IFO made it possible to obtain the necessary loans for reforms (Table 2).

In the 1990s, Latin American countries embarked on the path of integration into the world economy, in particular by abandoning protectionism, reducing administrative and market mechanisms in the economy, privatizing and reducing the public sector, and revising monetary policy. The multi-vector nature of central banks has been reduced through the granting of greater political and operational independence by governments, which has allowed these banks to focus on curbing inflation.

An analysis of cooperation with IFO in Latin America has shown that as a result, most countries in the region have well-functioning and predictable macroeconomic policies, significant progress in improving the social and economic sphere, infrastructure development, education, and productivity. IMF loans had a positive effect on GDP growth, the state of international settlements, especially in Brazil and Mexico. It is important to note that at the beginning of the debt crisis in Mexico, and later during its spread to other major countries in the region, such as Brazil and Argentina, the IMF played the role of crisis manager.

${ }^{69}$ Williamson J. A (2008) Short History of the Washington Consensus. The Washington Consensus Reconsidered: Towards a New Global Governance / ed. by Serra N., Stiglitz J. Oxford : Oxford University Press, p. 6, 
Table 2

IMF LENDING TO LATIN AMERICA AND THE IMF, SINCE $1982^{70}$

\begin{tabular}{|c|c|c|c|c|}
\hline Country & Type of Mechanism & Period & $\begin{array}{l}\text { Loan amount } \\
\text { (million } S D R)\end{array}$ & $\begin{array}{c}\text { Amount of funds } \\
\text { used (million SDR) }\end{array}$ \\
\hline \multirow{6}{*}{ Mexico } & EFF & $1983-85$ & $3,410.63$ & $2,502.68$ \\
\hline & SBA & $1986-88$ & $1,400.00$ & $1,400.00$ \\
\hline & SBA & $1989-93$ & $3,729.60$ & $3,263.40$ \\
\hline & SBA & $1995-97$ & $12,070.20$ & $8,758.02$ \\
\hline & EFF & $1999-2000$ & $3,103.00$ & $1,939.50$ \\
\hline & FCL (6) & $2009-18$ & $\approx 50,000.00$ & 0 \\
\hline \multirow{6}{*}{ Brazil } & EFF & $1983-86$ & 95.00 & 95.00 \\
\hline & $\mathrm{SBA}$ & $1988-90$ & 64.13 & 64.13 \\
\hline & SBA & $1992-93$ & $1,102.50$ & 817.50 \\
\hline & $\mathrm{SBA}+\mathrm{SRF}$ & 1998-01 & 380.50 & 318.10 \\
\hline & $\mathrm{SBA}+\mathrm{SRF}$ & 2001-02 & 314.04 & 261.70 \\
\hline & $\mathrm{SBA}+\mathrm{SRF}$ & $2002-05$ & 320.50 & 94.27 \\
\hline \multirow{12}{*}{ Argentina } & SBA & $1983-84$ & $1,500.00$ & 600.51 \\
\hline & SBA & $1984-86$ & $1,182.50$ & $1,182.50$ \\
\hline & SBA & $1987-88$ & 947.50 & 616.50 \\
\hline & SBA & 1989-91 & 736.00 & 506.00 \\
\hline & SBA & $1991-92$ & 780,00 & 438,75 \\
\hline & EFF & $1992-96$ & $4,020.25$ & $4,020.25$ \\
\hline & SBA & 1996-98 & 720.00 & 613.00 \\
\hline & EFF & $1998-2000$ & $2,080.00$ & 0 \\
\hline & $\mathrm{SBA}+\mathrm{SRF}$ & $2000-03$ & $23,023.46$ & $15,631.26$ \\
\hline & SBA & 2003 & $2,174.50$ & $2,174.50$ \\
\hline & SBA & 2003-06 & $8,981.00$ & $4,171.00$ \\
\hline & $\mathrm{SBA}$ & 2018-21 & $35,379.00$ & $10,613.71$ \\
\hline
\end{tabular}

${ }^{70}$ Developed by the authors based on IMF data, where EFF - Extended Fund Facility, SBA - Stand-by Arrangement and Supplemental Reserve Facility (ad hoc a mechanism used in conjunction with permanent EFF or SBA mechanisms in the late 1990s). 
It is also important to take into account the social and economic consequences of such cooperation. Studies have shown that the Bank's loans have not affected private consumption and the consumer price index, while in Argentina and Brazil they have affected employment level, and in Brazil and Mexico they have had an impact on human development, which was described in the growth of the Human Development Index. At the same time, experts note that the implementation of reforms had negative social consequences, including an increase in unemployment and the percentage of the poor.

At the same time, the Fund's loans did not have a decisive impact on inflation and international competitiveness, did not provide high economic growth, primarily because the measures proposed by the IMF to overcome the crisis were not adapted to the specifics of the region and led to a significant increase in external debt and caused dissatisfaction among the local population. The experience of Latin American countries has shown that countries cannot rely solely on favorable external conditions, in particular those provided by IFO, to stimulate future economic growth and must create their own favorable conditions, which can only be achieved through reform. At present, IMF remains the leading international player in the region, which will be able to provide the necessary assistance and advice on macroeconomic policy, as evidenced by the intensification of cooperation after the global financial crisis, particularly in Mexico and Argentina.

Central and Eastern European countries also cooperated with IFO. After the collapse of the Soviet Union in 1989, they had roughly the same starting point and focused on the social and economic transformation from socialism to capitalism, i.e. the creation of democratic institutions, the rule of law, and the free market ${ }^{71}$. During this period, most countries began active cooperation with IFO, and the IMO became a key organization in provision of financial and technical assistance to reform the region's national economies (Table 3).

In general, the IMF economic programs in Eastern Europe were aimed at eliminating macroeconomic and structural-institutional imbalances in the economies of transition economies. The Fund's assistance for stabilization and structural transformation programs in the countries of the region focused on:

- reduction of the balance of payments deficit, reduction of state subsidies to the national economy to limit budget expenditures;

- large-scale privatization of inefficient segments of the national economy, foreign economic reorientation of production;

\footnotetext{
${ }^{71}$ Aslund A. (2013) How capitalism was built : the transformation of Central and Eastern Europe, Russia, the Caucasus, and Central Asia. New York : Cambridge University Press. 1.
} 
- stimulation of the development of the financial sector, stock market, credit and financial institutions;

- liberalization of attraction and encouragement of foreign investments, transfers of financial assets, reparation of profits of foreign investors ${ }^{72}$.

Table 3

CHRONOLOGY OF THE BALTIC COUNTRIES' BORROWINGS FROM THE IMF BEFORE JOINING THE EUROPEAN UNION ${ }^{73}$

\begin{tabular}{|c|l|l|l|l|}
\hline \multirow{2}{*}{ Country } & \multicolumn{1}{|c|}{$\begin{array}{c}\text { Type of } \\
\text { Mechanism }\end{array}$} & \multicolumn{1}{|c|}{ Period } & $\begin{array}{c}\text { Loan amount } \\
\text { (million SDR })\end{array}$ & \multicolumn{1}{c|}{$\begin{array}{c}\text { Amount of funds used } \\
\text { (million SDR })\end{array}$} \\
\hline \multirow{3}{*}{ Estonia } & SBA & $1992-93$ & 27.90 & 27.90 \\
\cline { 2 - 6 } & SBA & $1993-95$ & 11.63 & 11.63 \\
\hline \multirow{3}{*}{ Latvia } & SBA & $1992-93$ & 54.90 & 54.90 \\
\cline { 2 - 6 } & SBA & $1993-95$ & 22.88 & 9.15 \\
\hline \multirow{3}{*}{ Lithuania } & SBA & $1992-93$ & 56.93 & 56.93 \\
\cline { 2 - 6 } & SBA & $1993-94$ & 25.88 & 5.18 \\
\cline { 2 - 6 } & EFF & $1994-97$ & 134.55 & 134.55 \\
\hline
\end{tabular}

The main purpose of such changes was not only to achieve and restore financial stability, but to achieve sustainable growth: economic growth in line with environmentally sustainable development, good governance and the equitable distribution of income and wealth.

According to our research, the countries in the region that have undergone the most market transformations are more successful, in particular Poland, Lithuania, Latvia and Estonia. Rapid implementation of social and economic transformations involving IFO resources was the basis for the creation of institutions that lead to systematic growth, in particular, property rights and their effective protection, healthy competition, effective budget planning and others ${ }^{74}$. Ultimately, the strengthening and rehabilitation of the financial system contributed to

${ }^{72}$ Sereda V.I. (2012). The role of the International Monetary Fund in maintaining the stability of economic development of countries with economies in transition (ukr. Rol Mizhnarodnoho valiutnoho fondu u pidtrymanni stabilnosti ekonomichnoho rozvytku krain z perekhidnoiu ekonomikoiu). Scientific Bulletin of the Academy of Municipal Administration. Ser. Economics (ukr. Naukovyi visnyk Akademii munitsypalnoho upravlinnia. Ser. Ekonomika), No. 12, p. 160. [in Ukrainian].

${ }_{73}$ Developed by the author on the basis of IMF data, where EFF — Extended Fund Facility, SBA — Stand-by Arrangement.

${ }_{74}$ Balcerowicz L. (2014). Who is to blame - the market or politics? Economic Growth After Socialism (rus. Kto vinovat - ryinok ili politika? Ekonomicheskiy rost posle sotsializma): Moscow: Foundation " Liberalnaya Missiya", p. 3, 11. [In Russian]. 
the creation of the necessary conditions for accession to the European Union. Today, all of Ukrainian eastern neighbors, except Moldova, are members of the EU. Convergence with the EU has resulted in an increase in average per capita income from about 30\% (EU-15) in the mid-1990s to about 50\% today, although there are significant differences between countries in terms of social and economic growth, wage growth, social guarantees from the state, but at the same time there is increasing productivity growth from investment and training of the workforce.

At the same time, the potential of universal IFO was insufficient to prevent crises, as well as to effectively overcome their consequences, which is associated with miscalculations in anti-crisis policy, disregard for regional specifics, requirements for too rapid privatization and market liberalization during market reforms and others.

The current stage of cooperation between IFO and Eastern European countries begins with the global financial crisis of 2008 and, as a result, the crisis in the Eurozone, which significantly affected the EU economy and relations with the IMF. The main priority areas of IFIO cooperation with Eastern European countries are the following:

1. ensuring further integration of countries into the world financial system, encouraging countries to pursue effective macroeconomic policies and structural reforms. The recent crisis and instability in the Eastern European region have led to a rethinking of the need to improve macroeconomic stability and financial independence by accelerating reforms in the country;

2. focusing on macroeconomic and financial stability indicators. In 2014, due to the political instability in the region, inflation affected some Eastern European countries, thus showing the shortcomings of the macroeconomic policy;

3. increasing the pace and depth of structural reforms. IFO cooperation with Eastern European countries cannot be effective without profound structural and institutional changes within the country. ${ }^{75}$

Since the early 2000s, radical reforms have slowed down in virtually all Central and Eastern European countries. Following the entry and membership obtainment of some Eastern European countries to the EU in 2004 and 2007 and the receipt of significant EU funding, these countries did not need to raise funds from IFO, but after the global

${ }^{75}$ Kulbida M.V. (2015). Cooperation of international financial organizations with Eastern European countries (ukr. Spivrobitnytstvo mizhnarodnykh finansovykh orhanizatsii iz krainamy Skhidnoi Yevropy). Scientific Bulletin of Kherson State University. Ser. Economic Sciences (ukr. Naukovyi visnyk Khersonskoho derzhavnoho universytetu. Ser. Ekonomichni nauky), No. 2 (2). - p. 24-29. [In Ukrainian]. 
crisis and the Eurozone crisis, full attention was paid to overcoming the crisis and not to the implementation of structural reforms.

Further cooperation with IFO will be aimed at strengthening the business environment, which is an important factor for the Eastern European region as a whole. This requires large-scale measures, including the promotion of corporate governance, securing property rights and fulfillment of contracts, implementation of administrative reform and improvement of legislation in the field of competition policy, resolution of insolvency issues and financial recovery, attracting foreign direct investment, as well as further integration into global markets for goods and services. For a number of countries, this also requires legislative and administrative reforms that are needed to improve public administration system.

The processes of transformation and cooperation with IFO in Asian countries have their own peculiarities. The economic transformations of Asian countries date back to the end of the World War II. Japan was the first country to start economic growth; In the 1960s, countries such as Hong Kong, Republic of Korea, Singapore, and Taiwan, also known as the "Asian Tigers", began to implement economic recovery programs aimed at foreign markets. Subsequently, this course was taken by other countries in the region - Indonesia, Malaysia and Thailand. Later, rapid growth began in China and India, which moved their own methods of gradual liberalization. In the mid-80s, a number of liberal reforms took place in these countries, which were aimed at improvement of macroeconomic regulation, supporting innovation and implementation of antitrust policies, loosening import controls, and reducing price regulation, a significant increase in wages.

IMF activities in East Asia began in the 1950s with the financial aid to Japan. Subsequently, the Fund provided technical assistance to the countries of the region, in particular, in the conduct of monetary policy, in the field of taxes, customs and tax administration, in the management of the balance of payments, the actions of the central bank, banking supervision, monetary policy, etc., as well as provided financial assistance through its programs/mechanisms to the countries of the region. Close cooperation of the countries of the region and the IMF occurred during the 1997-98 Asian financial crisis, caused by the processes of globalization. Countries such as Indonesia, Republic of Korea and Thailand had the largest borrowing volumes via the most popular credit lines: SBA, which is designed to help solve short-term balance of payments problems, medium-and long-term problems that have stimulated the economies of the region's countries by implementation of deep, effective reforms (Table 4). 
FUNDS ALLOCATED BY IFO TO OVERCOME THE CRISIS IN ASIA, USD billion ${ }^{76}$

\begin{tabular}{|l|c|c|c|c|}
\hline & IMF & $\begin{array}{c}\text { World Bank } \\
\text { and ADB }\end{array}$ & Other sources & Total \\
\hline Indonesia & 15.0 & 10.0 & 24.7 & 49.7 \\
\hline Republic of Korea & 21.1 & 14.2 & 23.1 & 58.4 \\
\hline Thailand & 4.0 & 2.7 & 10.5 & 17.2 \\
\hline Total & 40.1 & 26.9 & 58.3 & 125.3 \\
\hline
\end{tabular}

To overcome the crisis phenomena, the IMF managed, in addition to its own financial assistance in the amount of USD 40 billion, as a part of the economic stabilization mechanisms, to attract additional USD 85 billion from other sources, in particular from other IFO and governments of foreign countries.

The fund focused on reforming the financial system, tightening monetary policy, and reducing government interference in the financial system by severing close relations between business and government.

One of the indicators for assessment of the effectiveness of cooperation is the return of countries to GDP growth, especially rapid GDP growth was seen in the countries, which have attracted the most assistance from the IMF starting from the pre-crisis period; there was a significant recovery in economic indicators, flexibility and rapid recovery of economies after the last global financial crisis. Cooperation with IFO had a noticeable impact on the social development of creditor countries, for example, World Bank focused its activities on the problems of overcoming poverty, which in the context of rapid economic development was aimed at reducing the number of poor households, ensuring access to quality education and health, helping to improve public administration, access to services, creation of jobs and improvement of the legislative and security sphere, improvement of sanitary conditions in coastal cities, creation of an increasing number of infrastructure facilities, solid waste processing, etc.

Despite significant financial assistance in overcoming the Asian financial crisis, IMF activities in the region have a mixed assessment. Thus, some economists believed that the Fund interfered in areas beyond its competence ${ }^{77}$, while others believed that the Fund implemented

\footnotetext{
${ }^{76}$ Developed on the basis of IMF statistical data.

${ }_{77}$ Calomiris C. (1998) The IMF’s Imprudent Role as Lender of Last Resort Cato Journal, 17/3, p. 275-294.
} 
unfriendly market policies in the region ${ }^{78}$. However, most scientists criticize the longevity of the crisis and the too high cost of overcoming its consequences. In addition, there were suggestions about politicization of the decision-making within the $\mathrm{IMF}^{79}$. According to Takagi S., the confirmed gaps in the IMF activities during the crisis are: failure of the IMF to foresee the vulnerability of national economies, in particular in Indonesia and Republic of Korea; IMF credit mechanisms were poorly thought out, in particular in terms of fiscal policy; IMF required structural changes in the areas not relevant to the resolution of the crisis, in particular in Indonesia and Republic of Korea ${ }^{80}$.

Important conclusions from the Asian financial crisis were drawn by IMF, in particular, it became clear that in the period of deep economic problems, more balanced and significant measures are needed in the implementation of programs and the conditions under which the IMF implements programs should be more selective and aimed at the specific needs of a particular country in the region. In general, there is a need for more balanced measures of IFO in implementation of programs, their selectivity and targeting the specific needs of a particular country in the region and taking into account the social consequences of their activities. Therefore, Fund began to carefully calculate the social consequences of the impact of implemented programs, thereby analyzing and improving the quality of assistance provided in the future.

In addition, this crisis has revealed the inability of existing international structures, including international organizations, in particular IMF, neither to prevent the development of global crises nor to effectively address them. It is commonly known that, the fund's specialists themselves later admitted that the organization was not able to correctly identify the causes of the crisis, develop competent actions to get out of it and eliminate negative consequences, and also did not have enough financial resources to stop negative trends. It is clear that IMF could offer better crisis management strategies for the countries of the region and that a crisis management system should be created and strengthened. This can be done through adequate government actions and timely provision of large-scale international assistance (via IMF or regional development banks), which, in turn, will prevent an economic downturn and a sharp reduction in national reserves ${ }^{81}$.

\footnotetext{
${ }^{78}$ Radelet S., Sachs J. (2000) The Onset of the East Asian Financial Crisis. In: Krugman P. ed. Currency Crisis. Chicago: University of Chicago Press, p. 105-153.

Feldstein M. (1998) Refocusing the IMF. Foreign Affairs [online] Available at: https://www.foreignaffairs.com/articles/asia/1998-03-01/refocusing-imf.

${ }^{80}$ Takagi S. (2016) The IMF and East Asia: the legacy of the crisis and actions for the future. International Institutions and Asian Development, p. 74-96.

${ }^{81}$ Kulbida M. (2017) International Monetary Fund and East Asia: Developments, Challenges, and Lessons Learned. Baltic Journal of Economic Studies, 3/5. p. 244-251.
} 
At the same time, the failure of IFO to respond to challenges in a timely manner and provide the global economic system with the necessary liquidity to overcome crisis trends leads to gradual convergence of countries at the regional level, the development of multilateral mechanisms for strengthening regional financial stability and initiatives aimed at increasing the rate of economic growth within the region. It was recognized that a well-developed regional structure could contribute to the financial stability of the countries of the region in three ways:

- there is no need to rely only on the IMF for anti-crisis policy;

- regional cooperation mechanisms allow for more effective prevention and management of financial risks;

- the regional framework for financial cooperation is logical, given the strong regional economic and financial interdependence in the region.

Therefore, the cooperation of the countries of the region with IMF had both positive and negative consequences. On the one hand, the financial measures proposed by IMF to overcome the crisis were: abandoning the fixed exchange rate and pegging to the US dollar; raising the refinancing rate to strengthen national currencies; implementing strict fiscal policies to reduce the state budget deficit, as well as greater openness of markets to foreign capital to develop competition and internationalization of national economies, and so on. On the other hand, the implementation of these recommendations had a negative impact on the social and economic sphere, namely: decline in national production, massive bankruptcies of medium and small businesses, rising unemployment, reduced imports, falling living standards of the population, increased social and political tension.

\section{Problems and prospects of Ukraine's Cooperation with the International Monetary Fund}

Ukraine joined cooperation with the IMF and the World Bank in 1992. In 1994-95, active cooperation with the IMF began under the system transformation loan program, under which Ukraine received about USD 700 million to support of the balance of payments. Further cooperation became systematic, and loans amount to billions of US dollars. Over the years of cooperation, Ukraine and the IMF have agreed on 10 loan programs, including two of which provided for the use of an extended fund facility, and the remaining eight - stand-by arrangements. Under these programs, Ukraine could receive SDR 51.5 billion, but in fact received less than half - SDR 21.9 billion (approximately USD 31.5 billion) (Table 5). 
Table 5

CHRONOLOGY OF IMF LOAN PROGRAMS IN UKRAINE*82

\begin{tabular}{|c|c|c|c|c|c|c|}
\hline No. & $\begin{array}{c}\text { Credit } \\
\text { mechanism }\end{array}$ & Starting date & $\begin{array}{c}\text { Completion } \\
\text { date }\end{array}$ & $\begin{array}{l}\text { Agreed } \\
\text { amount }\end{array}$ & $\begin{array}{l}\text { Obtained } \\
\text { funds }\end{array}$ & $\begin{array}{c}\text { Outstanding } \\
\text { amount }\end{array}$ \\
\hline 1 & SBA & Dec. 18, 2018 & Feb. 17, 2020 & 2.800 .000 & 1.000 .000 & 1.000 .000 \\
\hline 2 & EFF & Apr. 11, 2015 & Dec. 17, 2018 & 12.348 .000 & 6.178 .260 & 6.178 .260 \\
\hline 3 & SBA & Apr. 30, 2014 & Mar. 10, 2015 & 10.946 .000 & 2.972 .670 & 114.334 \\
\hline 4 & SBA & Jul. 28, 2010 & Dec. 27, 2012 & 10.000 .000 & 2.250 .000 & 0 \\
\hline 5 & SBA & Nov. 05, 2008 & Jul. 28, 2010 & 11.000 .000 & 7.000 .000 & 0 \\
\hline 6 & SBA & Mar. 29, 2004 & Mar. 28, 2005 & 411.600 & 0 & 0 \\
\hline 7 & EFF & Sept. 04, 1998 & Sept. 03, 2002 & 1.919 .950 & 1.193 .000 & 0 \\
\hline 8 & SBA & Aug. 25.08.1997 & Aug. 24, 1998 & 398.920 & 181.328 & 0 \\
\hline 9 & SBA & May 10.05.1996 & Feb. 23, 1997 & 598.200 & 598.200 & 0 \\
\hline 10 & SBA & Apr. 07.04.1995 & Apr. 06, 1996 & 997.300 & 538.650 & 0 \\
\hline \multicolumn{4}{|r|}{ Total: } & 51449.970 & 21912.108 & 7292.594 \\
\hline
\end{tabular}

*(as of July 31, 2019), SDR

Given the negative impact of exogenous factors caused by the global pandemic and the inability to ensure the receipt of significant resources from foreign economic activity, further attraction of loans from IFO and other creditors and donors is inevitable. Therefore, in conditions of limited investment opportunities for the development of the national economy, IFO loans play an important role in the implementation of financial and monetary policies that would correspond to the achieved levels of economic stability and economic growth. Today, without a doubt, Ukraine has no other more profitable and reliable creditors, except the IMF. In addition, the active cooperation with the IMF allows us to receive assistance from the World Bank, the European Union and other creditors.

Over the past few years, Ukraine has used two of the most popular mechanisms for providing financing from the IMF, namely the EFF structural reform program and the SBA short-term financing ${ }^{83}$. Thus, in

\footnotetext{
${ }^{82}$ Developed on the basis of IMF data (where EFF — Extended Fund Facility, SBA — Stand-by Arrangement): IMF (2020) Ukraine: Transactions with the Fund from May 01, 1984 to April 30, 2020. URL: https://www.imf.org/external/np/fin/tad/extransl.aspx?memberKeyl=993\&endDate=2099\%2D12\%2D31\&finpositi on_flag=YES

${ }^{83}$ Kulbida M.V. (2018). IMF lending to developing countries (ukr. Kredytuvannia MVF krain, shcho rozvyvaiutsia). Intelligence of the XXI century (ukr. Intelekt XXI stolittia), No. 4, 13-18 p. [In Ukrainian].
} 
2015, the EFF program was agreed, which was aimed at restoring macroeconomic stabilization in Ukraine, implementation of structural reforms and creation of the basis for social and economic growth, in particular, a number of key reforms were implemented in the energy sector, the banking sector, the independence of the NBU, improvement of public finances, reforming the sector of state-owned enterprises and fighting corruption ${ }^{84}$. At the end of 2018, it was changed to the new SBA financial support program, which was created taking into account the reforms carried out under the previous program and focuses on maintenance of macroeconomic and financial stability, in particular continuance of financial consolidation to reduce public debt; maintenance of a flexible exchange rate and further reduction of inflation; strengthening the financial sector and reviving bank lending; support of further structural reforms, in particular improvement of the system of taxation, privatization and management.

The analysis of the consequences of Ukrainian cooperation with the IMF is ambiguous. On the one hand, the analysis of cooperation shows that one of the key structural reforms implemented in recent years is the reform of the banking sector, which now ensures the stabilization of the national financial system and creates prerequisites for sustainable economic growth. The Fund's activities in Ukraine help restore financial viability by provision of recommendations for effective implementation of structural reforms.

It is worth noting that a significant part of the funds raised from the IMF was used to stabilize the financial situation in the country, increase national reserves, finance the balance of payments deficit, service external debt, and so on. Loans provided by the IMF are noninflationary in nature, that is, such loans are beneficial for Ukraine, without them, the scale of the economic crisis and its consequences would be much more significant. The formation, including thanks to IMF loans, of the NBU foreign exchange reserves made it possible to maintain the stability of the national currency, successfully carry out monetary reform, and eventually introduce full convertibility of the hryvnia for current transactions. It became possible to accelerate the formation of the national monetary and financial system and gold and foreign currency reserves of Ukraine thanks to the receipt of funds from IFO. Such resources made it possible to ensure the implementation of an effective monetary policy, which resulted in a reduction in the rate of inflation, investment and foreign exchange resources entering the

\footnotetext{
${ }^{84}$ Kulbida M.V. (2018). Directions for improving cooperation between Ukraine and the IMF (ukr. Napriamy vdoskonalennia spivrobitnytstva Ukrainy ta MVF). Scientific Bulletin of Uzhhorod National University. Ser. International Economic Relations and the World Economy (ukr. Naukovyi visnyk Uzhhorodskoho natsionalnoho universytetu. Ser. Mizhnarodni ekonomichni vidnosyny ta svitove hospodarstvo), No. 22 (2), p. 52. [In Ukrainian].
} 
country, as well as the formation of a market environment in infrastructure and the development of financial mechanisms ${ }^{85}$. In addition, the increase in foreign currency reserves and their high level confirms the stability of the country's financial system and increases the level of confidence in it. As world practice shows, lending by the IMF (on concessional conditions, compared to market conditions) provides countries with a certain amount of time to implement structural adjustment policies and reforms that will restore the conditions for stable and sustainable economic growth, employment and social investment ${ }^{86}$.

Cooperation with IFO has also had positive consequences for Ukraine in terms of expansion of experience, creation of the necessary legislative framework and updating of public administration mechanisms, assurance of macroeconomic and financial stability, development of the private sector, creation of a favorable environment for economic growth in conditions of limited own resources and opportunities for commercial loans in the foreign market, getting the opportunity to apply the best world experience, technical assistance, analytical and forecast data of these organizations, that allows for better assessment and analysis of economic, social and macroeconomic policies at the national level.

On the other hand, experts also note shortcomings in Ukrainian cooperation with the Fund, and there are several reasons for this. First of all, there is the problem of the efficiency of using the funds received, because late and/or incomplete use of borrowing to fulfill the conditions of structural adjustment and macroeconomic stabilization programs leads to a slowdown in relevant reforms and projects, postponement or delay in their implementation, in some cases to the cancellation of allocated funds, and as a result - to inefficient use of budget funds ${ }^{87}$. Experts see the reason for this in directing financial assistance only to cover numerous external debts, instead of using these funds as a resource for implementation of an economically profitable long-term strategy, stabilization and improvement of the social and economic situation, creation of prerequisites for further sustainable development, as well as avoidance of crisis phenomena in the future.

\footnotetext{
85 Kolosova V.P., Kaplenko O.I. (2011). Partners of Ukraine to attract foreign investment (ukr. Partnery Ukrainy dlia zaluchennia inozemnykh investytsii). World economic situation and international mobility of factors of production (ukr. Svitova ekonomichna koniunktura ta mizhnarodna mobilnist faktoriv vyrobnytstva): materials of the International scientific-practical conf., Sept.16, 2010, Ternopil — Dresden, p. 79-89. [In Ukrainian].

${ }^{86}$ Sidenko S.V. (2011). Non-economic factors of world economic development (ukr. Neekonomichni chynnyky svitovoho ekonomichnoho rozvytku). Kyiv: Aurora-Print. [In Ukrainian].

${ }^{87}$ Londar L.P. (2016). Improving debt policy as a factor in increasing the level of financial security of the state (ukr. Vdoskonalennia borhovoi polityky yak chynnyk pidvyshchennia rivnia finansovoi bezpeky derzhavy). Strategic Priorities (ukr. Stratehichni priorytety), 3, p. 244-252. [In Ukrainian].
} 
Obtainment of loans from the IMF also led to a critical increase in the country's external public debt, which due to the lack or insufficiency of systemic reforms in the most important social and economic spheres, chronic non-fulfillment of the fund's conditions, as well as constant political and economic crises in Ukraine, led to a critical aggravation of the balance of payments deficit, and the slow reform of both financial and economic mechanisms and social and economic structural reforms further aggravated this situation. Finally, the allocation of the IMF loans is often accompanied by requirements for optimization of budget expenditures, which affects social and economic programs.

Thus, the long-term experience of cooperation between Ukraine and IFO indicates the need to form a qualitatively new approach to the general understanding of the role of international assistance of a diverse nature and resources of IFO as complementary tools on the way for the implementation of the state policy of international integration of our country, social and economic development, ensuring the interests of Ukraine in international economic relations.

According to Danylyshyn B., building relations with the IMF, cooperation with which requires fulfillment of liabilities on guidelines and measures of economic policy on a wide range of issues, should be based on two directions - on the one hand, institutional and structural reforms, on the other hand - modern industrial policy, which, ultimately, will lead to sustainable economic growth ${ }^{88}$. Structural reforms, which the IMF has emphasized during various loan programs, are now inevitable for Ukraine, and the fund's assistance contributes not only to stabilization in the country's macroeconomics and finances, but also creates a kind of pressure to implement unpopular but necessary reforms. Thus, in order to improve the efficiency of using IFO loans, there is a need for effective institutional and structural reforms in all sectors of the economy to improve the business environment and corporate governance.

It is obvious that the new stage of cooperation between Ukraine and IFO requires the development of a qualitatively new approach, as well as qualitatively new organizational mechanisms for relations. According to Filipenko A.S. when creating the conceptual foundations of Ukrainian foreign economic strategy, it is necessary to consider the fundamental changes that IFO, in particular the World Bank and the IMF, are undergoing. On the one hand, Ukrainian cooperation with IFO contributes to the inflow of additional financial and other resources

${ }^{88}$ Danylyshyn B.M. (2016) Cooperation with the IMF: problems and prospects (ukr. Spivrobitnytstvo z MVF: problemy i perspektyvy). URL: https://dt.ua/macrolevel/spivrobitnictvo-z-mvf-problemi-i-perspektivi-_.html. [In Ukrainian]. 
to the national economy, uses technical assistance in the process of implementation of market reforms, and develops an adequate economic policy. On the other hand, such cooperation makes it possible to introduce generally recognized norms and standards of statistical information, accounting and auditing, etc. into the national economic system $^{89}$.

With the aim to solve this type of organizational problems, the Government of Ukraine needs to have not only political will, but also a clear vision of the main tasks, the implementation of which will lead to an increase in the effectiveness of bilateral cooperation. The strategic directions of further cooperation should be:

- modernization of organizational mechanisms for implementation of the principle of geo-economic (European integration) and social and economic (technological and structural renewal, export development, business environment stimulation) priority of IFO programs and projects in Ukraine;

- design of a medium-term development strategy that includes optimization of the attraction of resources (funds and technical assistance) from external sources, considering the debt burden and the possibility of its restructuring;

- improvement of the efficiency and transparency of the use of external resources in the national economy aimed at social and economic growth $^{90}$.

Recent trends in global development indicate that Ukraine will continue to cooperate with IFO. With the spread of the pandemic in the world, the social and economic situation in Ukraine, as in most countries, has significantly worsened. Moreover, according to the IMF estimates, by the end of the year, the country's economy may reduce by $7.7 \%$. According to the NBU, in April, the business activity index fell below 30 points. Therefore, $60 \%$ of companies need up to one year to fully resume work, and $28 \%$ of companies lost up to half of their revenue $^{91}$. In these circumstances, cooperation with IFO will help solve priority problems to overcome the economic crisis.

Therefore, in the modern conditions of world development, the model of economic development includes broad integration into international economic and financial institutions to ensure participation in

${ }^{89}$ Filipenko A.S. (2010). Economic globalization: origins and results (rus. Ekonomicheskaya globalizatsiya: istoki i rezultatyi). Moscow: Economics (rus. Ekonomika). [In Russian].

90 Kulbida M.V. (2020). International financial organizations in the socio-economic processes of transformation of the world: author. dis... k-ta econ. Science, spec. 08.00.02. Kyiv: Kyiv National Economic University named after Vadym Hetman, p. 4-5. [In Ukrainian].

${ }^{91}$ How much did quarantine cost Ukrainians? Ten major losses. URL:

https://www.bbc.com/ukrainian/features-52773647?xtor=AL-73-\%5Bpartner\%5D-\%5Bukr\%5D$\% 5$ Bheadline $\% 5$ D-\%5Bukrainian $\% 5$ D-\%5Bbizdev $\% 5$ D-\%5Bisapi $\% 5$ D. [In Ukrainian]. 
international cooperation and division of labor, receives significantly more dividends for social and economic growth, access to technological innovations, receives additional advantages in increasing efficiency and reducing the cost of production, ensuring international competitiveness. Moreover, flexibility and rationality of relations with IFO can bring significantly more success in the medium and long term, provided that IFO loans are directed to the development of the economy, the creation of new industries and jobs, which will ensure economic growth and social development.

\section{Conclusions}

International financial organizations occupy an important place in the world economy and international economic relations, and their activities contribute to strengthening macroeconomic stability, solving a number of social and economic issues, integration of national economies into the world economy and enhancing the participation of countries in international monetary and credit relations. These organizations are a key element of the institutional framework of the global financial system and accumulate a significant amount of financial resources, which makes it possible to have a significant impact on both economic development and the functioning of international business in countries and regions of the world.

In the context of new global risks, the role of IFO is growing. The activities of international organizations are becoming of great importance in the context of the modern global pandemic, since these processes have covered all countries of the world and all spheres of human existence - the economy, politics, healthcare, etc. IMF experts have different assessments of the current crisis: some argue that it is the worst since the Great Depression of the 1930s, when the economies of developed countries reduced by $16 \%$ and the world as a whole reduced by about $10 \%$, while others believe that it is not so large. According to the IMF, due to the COVID-19 pandemic and quarantine measures in most countries this year the world economy will reduce by $3 \%$, and in developed countries the reduction will be twice as large - more than $6 \%$, the total loss of the world economy this year will be about USD 9 trillion. This is more than the economies of such powerful countries as Japan and Germany combined. For comparison, the IMF reminded that during the last global financial crisis in 2009, the world economy reduced by only $0.1 \%$ and then the economies of developing countries did not reduce, but, on the contrary, became a driver of recovery ${ }^{92}$. A

\footnotetext{
URL:

92 Coronavirus and the economy: The IMF predicts the worst crisis in almost 100 years. $B B C$. 「In Ukrainian]. https://www.bbc.com/ukrainian/features-52773647?xtor=AL-73-\%5Bpartner\%5D-\%5Bukr\%5D-
} 
feature of the current economic crisis is the huge losses that all countries in the world are suffering at the same time.

Therefore, the recovery of the world economy will require not only significant financial resources, but also consulting assistance, anti-crisis measures, analytical developments that can be provided by IFO. At the same time, important issues will need to be solved by other international organizations, including the World Health Organization, in connection with the need to overcome the pandemic; International Labor Organization - to develop recommendations for the solution of employment problems in the context of rising unemployment; International Organization for Migration - to improve the regulation of migration processes, etc. Only a coordinated policy of the world community can provide a solution to today's global problems.

\section{References}

1. Aslund A. (2013) How capitalism was built: the transformation of Central and Eastern Europe, Russia, the Caucasus, and Central Asia. New York : Cambridge University Press.

2. Balcerowicz L. (1999) Socialism, capitalism, transformation. Essays at the turn of the century (rus. Sotsializm, kapitalizm, transformatsiya. Ocherki na rubezhe epoh). Moscow: Nauka. [In Russian].

3. Balcerowicz L. (2014). Who is to blame - the market or politics? Economic Growth After Socialism (rus. Kto vinovat - ryinok ili politika? Ekonomicheskiy rost posle sotsializma): Moscow: Foundation " Liberalnaya Missiya", p. 3, 11. [In Russian].

4. Banerjee A. V., Duflo E. (2019) Good Economics for Hard Times. New York : Public Affairs.

5. Bardin A.L. (2015) The role of international financial institutions in global political governance (Case of the International Monetary Fund and the World Bank) (rus. Rol mezhdunarodnyih finansovyih institutov v globalnom politicheskom upravlenii (na primere Mezhdunarodnogo valyutnogo fonda i Vsemirnogo banka): dis. ... Cand. polit. Sciences: 23.00.04. Moscow: MGIMO, p. 95. [In Russian].

6. Barnett M. N., Finnemore M. (1999) The Politics, Power, and Pathologies of International Organization. International Organization, 53 (4), p. 699-732.

7. Barnett M. N., Finnemore M. (2004) Rules for the World: International Organizations in the Global Politics. Ithaca : Cornell University Press.

8. Beck U. What is globalization / U. Beck. - M .: Progress-Tradition, 2001. 304 p. [In Russian].

9. Bilorus O.G., Yefimenko T.I. (2015) Financial globalization and European integration (ukr. Finansova hlobalizatsiia i yevrointehratsiia). Kyiv: AFU. [In Ukrainian].

\%5Bheadline\%5D-\%5Bukrainian\%5D-\%5Bbizdev\%5D-5Bisapi\%5D 
10. Bogomolov O.T., Nekipelov A.N. Economic globalization and the crisis of the world economic order (rus. Ekonomicheskaya globalizatsiya i krizis mirovogo hozyaytvennogo poryadka). - Facets of Globalization (rus. Grani globalizatsii). - p.105. [In Russian].

11. Boughton J. M. (2001) Silent revolution: the International Monetary Fund, 1979-1989. Washington D.C. : IMF.

12. Bradlow D., Hunter D. (2010) International Financial Institutions and International Law. New York : Kluwer Law International.

13. Castells M. Information Age: Economics, Society and Culture .: transl. from Eng. - M .: GU HSE, 2000. [In Russian].

14. Calomiris C. (1998) The IMF's Imprudent Role as Lender of Last Resort. Cato Journal, $17 / 3$, p. 275-294.

15. Chukhno A.A. (2003). Post-industrial economy: theory, practice and their significance for Ukraine (ukr. Postindustrialna ekonomika: teoriia, praktyka ta yikh znachennia dlia Ukrainy). Kyiv: Logos. [In Ukrainian].

16. Coronavirus and the economy: The IMF predicts the worst crisis in almost 100 years. $B B C$. [In Ukrainian]. URL: https: / /www.bbc.com/ukrainian / features-52773647?xtor=AL-73-

\%5Bpartner\%5D-\%5Bukr\%5D-\%5Bheadline\%5D-\%5Bukrainian\%5D-

\%5Bbizdev\%5D-5Bisapi\%5D

17. Danylyshyn B.M. (2016) Cooperation with the IMF: problems and prospects (ukr. Spivrobitnytstvo z MVF: problemy i perspektyvy). URL: https: / / dt.ua/macrolevel/spivrobitnictvo-z-mvf-problemi-i-perspektivi-_.html.

[In Ukrainian].

18. Dolishniy MI (2006) Regional policy at the turn of the XX-XXI centuries. New priorities (ukr. Rehionalna polityka na rubezhi 20-21 stolit. Novi priorytety). Kyiv: Nauk. dumka. [In Ukrainian].

19. Feldstein M. (1998) Refocusing the IMF. Foreign Affairs. URL: https: / / www.foreignaffairs.com / articles / asia / 1998-03-01 / refocusing-imf.

20. Filipenko A.S. (2010) Economic globalization: origins and results (rus. Ekonomicheskaya globalizatsiya: istoki i rezultatyi). Moscow: Economics (rus. Ekonomika). [In Russian].

21. Friedman T. (2000) The Lexus and the Olive Tree. New York : Anchor Books.

22. Galchynsky A. (2006) Global transformations: conceptual alternatives: Methodological aspects (ukr. Hlobalni transformatsii: kontseptualni alternatyvy: Metodolohichni aspekty). Kyiv: Lybid. [In Ukrainian].

23. Harari Y. N. (2018) 21 Lessons for the 21st Century. London: Vintage.

24. Ilyin M.V., Inozemtsev V.L. Megatrends of world development (rus. Megatrendyi mirovogo razvitiya). [In Russian].

25. International Finance (2016) / ed. by O.M. Mozgivyi et al.. Kyiv: KNEU. [In Ukrainian].

26. Keohane R. (2005) After Hegemony: Cooperation and Discord in the World Political Economy. Princeton : Princeton University Press.

27. Klymenko K.V. (2017). Foreign experience of cooperation with the International Bank for Reconstruction and Development and the International Development Association (ukr. Zarubizhnyi dosvid spivrobitnytstva z 
Mizhnarodnykh bankom rekonstruktsii ta rozvytku i Mizhnarodnoiu asotsiatsiieiu rozvytku). Scientific works of NDFI (ukr. Naukovi roboty NDFI), No. 1, p. 16-40. [In Ukrainian].

28. Kolodko G.V. (2010) The Great Transformation (rus. Velikaya transformatsiya). Century of Globalization (rus. Vek globalizatsii), No. 2, p. 6877. [In Russian].

29. Kolosova V.P. (2013). Cooperation of Ukraine with international institutions and sectoral budget support (ukr. Spivrobitnytstvo Ukrainy $\mathrm{z}$ mizhnarodnymy ustanovamy ta sektoralna biudzhetna pidtrymka). Kyiv: AFU, p. 40. [In Ukrainian].

30. Kolosova V.P. (2016). Finance of international institutions in Ukraine (ukr. Spivrobitnytstvo z MVF: problemy i perspektyvy). Kyiv: KNTEU. [In Ukrainian].

31. Kolosova V.P., Kaplenko O.I. (2011). Partners of Ukraine to attract foreign investment (ukr. Partnery Ukrainy dlia zaluchennia inozemnykh investytsii). World economic situation and international mobility of factors of production (ukr. Svitova ekonomichna koniunktura ta mizhnarodna mobilnist faktoriv vyrobnytstva): materials of the International scientific-practical conf., Sept.16, 2010, Ternopil - Dresden, p. 79-89. [In Ukrainian].

32. Kulbida M.V. (2015). Cooperation of international financial organizations with Eastern European countries (ukr. Spivrobitnytstvo mizhnarodnykh finansovykh orhanizatsii iz krainamy Skhidnoi Yevropy). Scientific Bulletin of Kherson State University. Ser. Economic Sciences (ukr. Naukovyi visnyk Khersonskoho derzhavnoho universytetu. Ser. Ekonomichni nauky), No. 2 (2). p. 24-29. [In Ukrainian].

33. Kulbida M. (2017) International Monetary Fund and East Asia: Developments, Challenges, and Lessons Learned. Baltic Journal of Economic Studies, 3/5. p. 244-251.

34. Kulbida M.V. (2018). IMF lending to developing countries (ukr. Kredytuvannia MVF krain, shcho rozvyvaiutsia). Intelligence of the XXI century (ukr. Intelekt XXI stolittia), No. 4, 13-18 p. [In Ukrainian].

35. Kulbida M.V. (2018). Directions for improving cooperation between Ukraine and the IMF (ukr. Napriamy vdoskonalennia spivrobitnytstva Ukrainy ta MVF). Scientific Bulletin of Uzhhorod National University. Ser. International Economic Relations and the World Economy (ukr. Naukovyi visnyk Uzhhorodskoho natsionalnoho universytetu. Ser. Mizhnarodni ekonomichni vidnosyny ta svitove hospodarstvo), No. 22 (2), p. 52. [In Ukrainian].

36. Kulbida M. (2019) International financial organizations in the system of global governance (ukr. Mizhnarodni finansovi orhanizatsii u systemi hlobalnoho upravlinnia). Current issues of international relations (ukr. Aktualni problemy mizhnarodnykh vidnosyn): materials of the International. scientific-practical conf., October 24, 2019, Kyiv: IIU KNU, p. 138-141. [In Ukrainian].

37. Kulbida M.V. (2020). International financial organizations in the socioeconomic processes of transformation of the world: author. dis... $k$-ta econ. Science, spec. 08.00.02. Kyiv: Kyiv National Economic University named after Vadym Hetman, p. 4-5. [In Ukrainian]. 
38. Liutyi I.O. (2008) State credit and debt policy of Ukraine (ukr. Derzhavnyi kredyt ta borhova polityka Ukrainy). Kyiv: Center for Educational Literature (ukr. Tsentr uchbovoi literatury), p. 139-238. [In Ukrainian].

39. Londar L.P. (2016). Improving debt policy as a factor in increasing the level of financial security of the state (ukr. Vdoskonalennia borhovoi polityky yak chynnyk pidvyshchennia rivnia finansovoi bezpeky derzhavy). Strategic Priorities (ukr. Stratehichni priorytety), 3, p. 244-252. [In Ukrainian].

40. Lukinov II (1997) Economic transformations (at the end of the XXI century) (ukr. Ekonomichni transformatsii (naprykintsi XXI storichchia). Kyiv: IN NASU. [In Ukrainian].

41. Lukyanenko D.H., Kalchenko T.V. (2008). Strategies of global governance. International Economic Policy, No. 1-2, p. 5-43.

42. McDowell D. (2017) Brother, Can You Spare a Billion? (The United States, the IMF, and the International Lender of Last Resort). Oxford : Oxford University Press.

43. Moiseev A.A. (2007). International financial organizations (legal aspects of activity). 2nd ed. Moscow: OMEGA, p. 10. [In Russian].

44. Naciri A. (2018) The Governance Structures of the Bretton Woods Financial Institutions. Montreal : Springer.

45. Ocampo J. A. and Titelman D. (2012) Regional Monetary Cooperation in Latin America. ADBI Working Paper 373. Tokyo : ADBI.

46. Patyka N.I. (2012). International monetary relations. Kyiv: Znannya. [In Ukrainian]

47. Radelet S., Sachs J. (2000) The Onset of the East Asian Financial Crisis. In: Krugman P. ed. Currency Crisis. Chicago: University of Chicago Press, p. 105-153.

48. Reznikova N.V., Ivashchenko O.A. (2017). Problems of reinstitutionalization of the world economy in the conditions of independence: new challenges to global regulation (ukr. Problemy reinstytutsionalizatsii svitovoi ekonomiky v umovakh neozalezhnosti: novi vyklyky hlobalnomu rehuliuvanniu). Economics (ukr. Ekonomichna nauka), No. 10, p. 5-6. [In Ukrainian].

49. Ricards J. (2015) Currency Wars. - transl. by E. Tortunova. Moscow: Eskmo. [In Russian].

50. Sachs J., Tornell A., Velasco A. (1996) The Mexican Peso Crisis: Sudden Death or Death Foretold. Journal of International Economics, 3-4, p. 265-283.

51. Sereda V.I. (2012). The role of the International Monetary Fund in maintaining the stability of economic development of countries with economies in transition (ukr. Rol Mizhnarodnoho valiutnoho fondu u pidtrymanni stabilnosti ekonomichnoho rozvytku krain z perekhidnoiu ekonomikoiu). Scientific Bulletin of the Academy of Municipal Administration. Ser. Economics (ukr. Naukovyi visnyk Akademii munitsypalnoho upravlinnia. Ser. Ekonomika), No. 12, p. 160. [in Ukrainian].

52. Sidenko V.R. (2017) Difficult dilemmas of renewing the global institutional architectonics (ukr. Trudnyie dilemmyi obnovleniya globalnoy institutsionalnoy arhitektoniki). Economy of Ukraine (ukr. Ekonomika Ukrainyi), No. 4 (657). [In Russian]. 
53. Sidenko V.R. (2018). Global structural transformations and trends of the Ukrainian economy (ukr. Hlobalni strukturni transformatsii ta trendy ekonomiky Ukrainy). Economics and Forecasting (ukr. Ekonomika i prohnozuvannia), 2, p. 7-28. [In Ukrainian].

54. Sidenko S.V. (2011) Non-economic factors of world economic development (ukr. Neekonomichni chynnyky svitovoho ekonomichnoho rozvytku). Kyiv: Aurora-Print. [In Ukrainian].

55. Sinclair J. T. (2012) Global Governance. Cambridge : Police Press.

56. Soros J. (2018) Open Society. Reforming global capitalism. Translation from English. A. Pitik, E. Hrytsaychuk. Kharkiv: Folio. [In Ukrainian].

57. Stiglitz D. Globalization: disturbing trends. - transl. from English, M., Mysl, 2003. [In Russian].

58. Stiglitz J. (2018) Globalization and Its Discontents Revisited: AntiGlobalization in the Era of Trump. New York : W. W. Norton \& Company.

59. Takagi S. (2016) The IMF and East Asia: the legacy of the crisis and actions for the future. International Institutions and Asian Development, p. 7496.

60. Toynbee A. J. Civilization before the Court of History: A Collection. transl. from English. - 2nd ed. - M.: Iris-press. 2003. [In Russian].

61. Truman E. (2006) Reforming the IMF for the 21st Century. Washington D.C. : Institute of International Economics.

62. Williamson J. A. (2008) Short History of the Washington Consensus. In: Serra N., Stiglitz J., eds. The Washington Consensus Reconsidered: Towards a New Global Governance. Oxford: Oxford University Press, p. 14-30.

63. World finances: modern tendencies and prospects of development: monograph (ukr. Svitovi finansy: suchasni tendentsii ta perspektyvy rozvytku ) (2013) / O.I. Rohach et al. Kyiv: KNU. [In Ukrainian].

64. Varnaliy Z.S. (2007). State regional policy of Ukraine: features and strategic priorities (ukr. Derzhavna rehionalna polityka Ukrainy: osoblyvosti ta stratehichni priorytety). Kyiv: NISD. [In Ukrainian].

65. Yakovets Yu. V. (2011). Global economic transformations of the XXI century (ukr. Globalnyie ekonomicheskie transformatsii XXI veka). Moscow: Economika. [In Russian].

66. Zhalilo Ya. A. (2009) Theory and practice of forming an effective economic strategy of the state (ukr. Teoriia ta praktyka formuvannia efektyvnoi ekonomichnoi stratehii derzhavy). Kyiv: NISD. [In Ukrainian].

The article was received by the Editorial Board on June 11, 2020. 